\title{
The UK Stewardship Code: On the Road to Nowhere?
}

\author{
Arad Reisberg*
}

\begin{abstract}
In this article I seek to demonstrate that, as drafted, the UK Stewardship Code (SC) is trivial, absent of meaning and incapable of achieving its goals. I will begin by demonstrating how little it has achieved to date and can expect to achieve going forward. In doing so I will reconsider arguments, advanced elsewhere, concerning the conceptual problems with the SC, specifically; how it is drafted and upon what it focuses. I will then advance new concerns about the practical issues of the SC that make it a blunt tool of corporate governance but go on to show that there are a number of potential ways to change this. In doing so I hope to provide the impetus to divert the SC from its current path, travelling along the road to nowhere, and instead seek a journey that not only has a destination but a much more promising one.
\end{abstract}

Keywords: Stewardship, Shareholders, Engagement, Corporate Governance, Directors, Long Term, Institutional shareholders, The UK Stewardship Code

We're on a road to nowhere
Come on inside
Takin' that ride to nowhere
We'll take that ride
$\ldots$
And it's very far away
But it's growing day by day
$\ldots$
And the future is certain

Give us time to work it out ${ }^{1}$

\footnotetext{
* Arad Reisberg, Reader in Corporate and Financial Law, UCL Faculty of Laws. I am grateful to the Brooklyn Law School's generosity in providing funds to support this project, which was largely conceived at the time I spent as a Visiting Professor at the School during the Fall Term of 2012. I am also grateful for comments and feedback provided by participants on earlier drafts at the following seminars/symposiums: 'Comparative Corporate Governance Distinguished Lecture Series' co-sponsored by the Corporate Law Center and the Office of International and Non-J.D. Programs at Fordham Law School, New-York on 18 October 2012, at a comparative corporate governance seminar at Penn Law School on 4 December 2012, at a symposium at Waseda University, Tokyo on 19 February 2013 and at a jointly organized seminar by Continuing Legal Education and the Centre for Law \& Business at the Faculty of Law, National University of Singapore (NUS) on 20 March 2013. I am grateful to Alina Levi for providing excellent research assistance during my time at Brooklyn Law School in Fall 2012, to Eleanore Hickman for providing the same at UCL, to Erika Barros Sierra Cordera for assisting me in finally putting my ideas to paper, and to Bobbi Bullock for first class secretarial assistance. Thanks are also due on feedback received on earlier drafts of the article by Edward Walker-Arnott and Hans-Christoph Hirt. The usual disclaimers apply.

1 'Road To Nowhere' by the band Talking heads from their 1985 album Little Creatures. Songwriters: D Byrne, T Weymouth, C Frantz and J Harrison.
} 


\section{A. Background}

\section{Introduction}

In this article, I question the extent of headway that has been achieved to date with the Financial Reporting Council's (FRC) ${ }^{2}$ Stewardship Code (SC) and suggest that significant challenges need to be addressed if the SC is to deliver on enhancing "the quality of engagement between asset managers and companies to help improve longterm risk-adjusted returns to shareholders." "Understanding this, the article goes on to suggest ways in which the aims of the SC can more realistically be achieved. Section A provides a brief introduction to the context of UK corporate governance. Section B describes the particular circumstances surrounding the 'birth' of the SC, the problem it was trying to fix and an analysis of how (un)successful it has been. Section C analyses why and how the SC failed to meet expectations and become a meaningful corporate governance mechanism. It provides a detailed account of the SC's 'structural' weaknesses by focusing on two major and familiar arguments: ${ }^{4}$ (i) that, in rushing the drafting of the SC, depth and rigour were sacrificed for speediness and the need to produce a quick 'fix'; and (ii) that the SC detracts from the real discussion to be had by avoiding the questions which should have been asked. Section D will go on to establish the extent of the damage caused by the errors and demonstrate how the consequence is a master class in meaninglessness and ultimately a voyage with no destination. Section E draws lessons from the preceding discussion and provides some signposts for the future. Finally, section F concludes.

\section{The Corporate Governance Context}

Corporate regulation around the world "increasingly depends on a complex network of interacting and mutually reinforcing legal rules, non-enforceable norms and practices." As previously observed, the UK has long been seen as an international leader "in the development of successful non-statutory voluntary codes and guidance relating to corporate affairs. These include the Takeover Code and the various corporate governance codes that were developed by committees in the 1990s (starting with Cadbury, ${ }^{6}$ then Greenbury ${ }^{7}$ and followed by Hampel ${ }^{8}$ ), much of the substance of which has now been consolidated into the UK Corporate Governance Code (CGC) ${ }^{9}$ (formerly the Combined Code) based on the 'comply-or-explain' regime (explained below)." 10

\footnotetext{
${ }^{2}$ The FRC is the UK's independent regulator responsible for promoting confidence in corporate governance, including through excellent corporate reporting. See https://www.frc.org.uk/About-the-FRC.aspx (accessed 21 March 2014).

${ }^{3}$ The FRC on the UK Stewardship Code. Available at:

https://www.frc.org.uk/Our-Work/Codes-Standards/Corporate-governance/UK-Stewardship-Code.aspx (accessed 28 April 2014).

${ }^{4}$ See for example L Roach, 'The UK Stewardship Code' (2011) Journal of Corporate Law Studies, 463, B Cheffins, 'The Stewardship Code's Achilles' Heel' (2010) 73 Modern Law Review 1004, and A Reisberg, 'The Notion of Stewardship from a Company Law Perspective: Re-defined and re-assessed in light of the recent financial crisis?' (2011) 18 Journal of Financial Crime 126, to name three.

${ }^{5}$ E Ferran, 'Company Law Reform in the UK', 17, available at: http://ssrn.com/abstract=294508 (accessed 17 March 2014).

${ }^{6}$ A Cadbury, Report to the Committee on the Financial Aspects of Corporate Governance (1 December 1992), Gee and Co Ltd.

${ }^{7}$ L. Matt (ED), Directors' Remuneration, Report of a Study Group chaired by Sir Richard Greenbury (17 July 1995) ECGI.

${ }^{8} \mathrm{R}$ Hampel, Committee on Corporate Governance: Final Report (Gee Publishing Ltd, January 1998).

${ }^{9}$ Available at: https://www.frc.org.uk/Our-Work/Publications/Corporate-Governance/UK-Corporate-Governance-CodeSeptember-2012.pdf (accessed 17 March 2014).

${ }^{10}$ A Reisberg 'Corporate Law in the UK after Recent Reforms: The Good, the Bad and the Ugly' (2010) 63 Current Legal Problems (Oxford University press) 315, 317-319. This is not to be underestimated, particularly as, over the same time period, British statutory rules on corporate law have become increasingly unattractive and inaccessible over the past half-century.
} 
The CGC is considered, by international standards, to be one of the leading benchmarks of what constitutes good corporate governance practice; domestic and foreign companies alike seek voluntarily to comply with its requirements as evidence of 'good corporate citizenship.' 11 The essential features of the code i.e. the flexibility of its 'comply or explain' approach and its adaptability, are praised not only in the UK but also more widely. ${ }^{12}$ Indeed, as can be seen from the "European Corporate Governance Institute's database of corporate governance codes, ${ }^{13}$ since the CGC was first published in 1992, it has been copied, transposed or adapted in every Member State of the European Union and in more than 60 other countries elsewhere in the world - with the notable exception of the US." ${ }^{14}$ Unsurprisingly therefore, expectations were high for the SC. Indeed, it remains the case that other jurisdictions do look to the advances made in the UK in the corporate governance context. As recently as 2014, the SC has been upheld as a shareholder engagement tool to which other jurisdictions should aspire. ${ }^{15}$ But before any such view can be endorsed, this allegedly aspirational code needs much closer scrutiny.

\section{B. The UK Stewardship Code}

\section{The problem}

Before considering what the SC aimed to achieve and whether it achieved those aims, it is important to understand what problem the FRC were trying to tackle through the SC's development. What was actually going wrong?

Institutional investors were repeatedly being blamed, in the wake of the financial crisis, for being part of the problem that led to the markets' crash that, to this day, afflicts the global financial markets. Questions were raised about the role they had played; in particular, their lax engagement, passivity and evident disinterest in exercising proper oversight of their companies was denounced and widely criticised. The crisis had highlighted a gap between the corporate governance standards (as set out in the CGC, or as it was known previously the Combined Code) and the actual practices of major companies. Supporters of the CGC considered this to be the result of a problem regarding the application of the 'comply or explain' approach, rather than of the principle itself, and identified shareholders as being part of this problem. ${ }^{16}$ They argued that the success of the approach was dependent to a great extent on high volume of investors who choose active engagement with companies. From this perspective, the diligent exercise of shareholders' stewardship role became essential "to reinforce the positive effect of "comply or explain".. ${ }^{17}$ The European Commission

\footnotetext{
${ }^{11}$ M Barrett, "The end of "comply or explain"? Corporate governance in the United Kingdom and Ireland and the impact of CRD IV' (2012) 27(1) Journal of International Banking Law and Regulation 4, 11.

${ }^{12}$ Ibid.

${ }^{13}$ This database is generally accepted as the most comprehensive and up-to-date record, currently containing over 350 codes, code revisions or code-like documents. Available at: www.ecgi.org/codes (accessed 30 March 2014).

${ }^{14} \mathrm{M}$ Becht, 'Comply or Just Explain?' in 20th Anniversary of the UK Corporate Governance Code Financial Reporting Council (London, 2012), 11. As Simpson noted: "the approach of the CGC has also been reflected in guidelines and principles issued by inter-governmental groups such as the Organisation for Economic Co-operation and Development (OECD) and the World Bank Group. Even CalPERS, in the United States, a market marked by the absence of a national code, calls upon countries to develop codes of practice in order to raise standards of corporate governance." See A Simpson, 'The Power of Example' in 20th Anniversary of the UK Corporate Governance Code Financial Reporting Council, (London, 2012), 49.

${ }^{15}$ Z Tan, 'Stewardship in the Interests of Systemic Stakeholders: Re-Conceptualizing the Means and Ends of Anglo-American Corporate Governance in the Wake of the Global Financial Crisis' (2014) 9 J Bus \& Tech L 169, 211.

${ }^{16}$ Sir John Parker 'Commercial Freedom, Sound Governance' in 20th Anniversary of the UK Corporate Governance Code, Financial Reporting Council (London, 2012), 43-44.

${ }^{17}$ Ibid.
} 
weighed in, arguing that, "a lack of appropriate shareholder interest in holding financial institutions' management accountable contributed to poor management accountability and may have facilitated excessive risk taking in financial institutions." 18 Lord Myners (at the time the Financial Services Secretary to the Treasury) memorably coined the term 'absentee landlords' to describe institutional investors, while at the same time, claiming that the inactivity displayed by them had contributed to the propagation of an 'ownerless corporation'. 19

But herein a paradox emerged. The UK had been among the leading forces pushing for the very policies that contributed to the development of the corporate governance system that was then being identified as contributing to the global melt down. The country's government was under increasing pressure from all fronts to find solutions to the problems arising from this system. Consequently, the UK Government felt the pressure to try and address these issues, including that of shareholder engagement. Something had to be done quickly and, preferably, visibly. Peter Montagnon, (then) senior Investment Adviser to the FRC, captured the mood at the time when he was quoted in the financial press in October 2010 saying that: "the system has been rocked to its core and investors know it. They have suffered and they don't want to suffer in the same way again." ${ }^{20}$ And so, the FRC announced the SC as the tool that would help improve the complex relationship between investors and investee companies. It was expected to tackle the obstacles that hinder this relationship and in its own words to "enhance the quality of engagement between asset managers and companies to help improve long-term risk-adjusted returns to shareholders." 21

\section{The purported solution}

In February 2009 Sir David Walker was commissioned to conduct a review of the governance of banks and other financial institutions and the role of institutional shareholders in engaging effectively with them. Seven months later, in November 2009, Walker issued a report (the Walker Review) where he recommended that:

"[T]he Code on the Responsibilities of Institutional Investors, prepared by the Institutional Shareholders' Committee, should be ratified by the FRC and become the Stewardship Code. By virtue of the independence and authority of the FRC, this transition to sponsorship by the FRC should give materially greater weight to the Stewardship Code. Its status should be akin to that of the

\footnotetext{
${ }^{18}$ European Commission, Green Paper The EU Corporate Governance Framework 2011, European Commission COM (2011) $164,11$.

${ }^{19}$ Lord Myners, 'Association of Investment Companies' (April 2009) in Roach, supra n 4, 467.

In March 2011 Lindsay Tomlinson, (then) the Chairman of the NAPF said in a speech at the annual NAPF Investment

Conference in Edinburgh that: "before the financial crisis, I kept on telling everyone I met that UK corporate governance, the combined code and the way in which UK investors behaved were the best in the world and were a model for others to copy. But ever since the banks blew up in 2008, I found it a difficult line to take. I've gone back to my bunker. It's hard to defend something that's failed to badly. What could or should we have collectively have done to avert the disaster?" See, http://www.napf.co.uk/Conferences_and_Seminars/Investment_Conference.aspx (accessed 30 April 2014).

${ }^{20}$ M Christodoulou, 'Profile: Peter Montagnon, senior investment adviser, FRC' AccountancyAge (21 October 2010) available at: http://www.accountancyage.com/aa/interview/1863342/profile-peter-montagnon-senior-investment-adviser-frc (accessed 30 April 2014). Tomlinson, supra n 19, described the mood in response to the SC: "Many pension funds have embraced the concept of corporate governance and understand that the Stewardship Code is merely an extension of the work previously undertaken by investors in the corporate governance area. But many have found it at best irritating, to be told they're failing in this area and that they need to pull up their socks."

${ }^{21}$ FRC, supra $\mathrm{n} 3$.
} 
Combined Code as a statement of best practice, with observance on a similar "comply or explain" basis.", 22

Pursuant to Walker's recommendations, the FRC agreed to take on responsibility for the development and oversight of the code. And so, the FRC announced the SC as the tool that would help improve the complex relationship between investors and investee companies. In July 2010, after a rushed 6-month consultation period, the now widely known FRC Stewardship Code $(\mathrm{SC})^{23}$ was published without making any major changes to the ISC's code. In other words, a 20-year old second hand was simply rebranded and sold to us as new. ${ }^{24}$

As can be seen in Table 1 below, the ISC was the first - and for a long time the only code (see period highlighted in the first two rows) - to attempt motivating investors' engagement. In November 2009 the ISC's Statement of Principles was reformatted as the Code on the Responsibilities of Institutional Investors. Then, in less than a year (or to be more precise within 9 months) - between November 2009 and July 2010 the FRC took over the responsibility to develop a new code, opened a consultation period and published the first working version of the SC. By all accounts a remarkably speedy affair.

Table 1 Chronology: The Birth (or reproduction) of the UK Stewardship Code

\begin{tabular}{|l|l|l|}
\hline 1991 & $($ ISC)* & $\begin{array}{l}\text { Statement on The } \\
\text { Responsibilities of Institutional } \\
\text { Shareholders in the UK } \\
* \text { ISC = Institutional Shareholders' } \\
\text { Committee (re-named the } \\
\text { Institutional Investor Committee } \\
\text { (IIC) on 18 May 2011) }\end{array}$ \\
\hline 2002 & ISC & $\begin{array}{l}\text { The Responsibilities of } \\
\text { Institutional Shareholders and } \\
\text { Agents: Statement of Principles }\end{array}$ \\
\hline November 2009 & Walker Review & $\begin{array}{l}\text { Invited the FRC to take } \\
\text { responsibility for the Code }\end{array}$ \\
\hline November 2009 & ISC & $\begin{array}{l}\text { Statement reformatted as Code on } \\
\text { the Responsibilities of Institutional } \\
\text { Investors }\end{array}$ \\
\hline January 2010 & FRC & $\begin{array}{l}\text { Consultation open on the 'new' } \\
\text { Code; Closed in April 2012 (74 } \\
\text { responses) }\end{array}$ \\
\hline July 2010 & $\begin{array}{l}\text { Code published - closely } \\
\text { mirrored the ISC code } \\
\text { (The ISC Code used as basis for } \\
\text { Code with minor amendments) }\end{array}$ \\
\hline
\end{tabular}

${ }^{22}$ D Walker, A Review of Corporate Governance in UK Banks and Other Financial Industry Entities: Final Recommendations (London, HM Treasury, 2009),17 available at: http://webarchive.nationalarchives.gov.uk/+/http:/www.hm-

treasury.gov.uk/d/walker_review_261109.pdf (accessed 2 December 2014), 17.

${ }^{23}$ Most recently in the revised version from September 2012, which came into effect on 1 October 2012. See FRC, UK Stewardship Code, at: http://www.frc.org.uk/Our-Work/Publications/Corporate-Governance/UK-Stewardship-Code-September2012.aspx (accessed 17 March 2014).

${ }^{24}$ For a thorough discussion on this point see Roach, supra n 4, 463-468. 


\begin{tabular}{|l|l|l|}
\hline April 2012 & FRC & $\begin{array}{l}\text { Consultation on amendments } \\
\text { open; Closed in July 2012 (65 } \\
\text { responses) }\end{array}$ \\
\hline 28 September 2012 & FRC & $\begin{array}{l}\text { Updated Code published; in } \\
\text { effect from 1 October 2012 }\end{array}$ \\
\hline & FRC & $\begin{array}{l}\text { Unless circumstances change, the } \\
\text { FRC does not envisage proposing } \\
\text { further changes to the Code until } \\
\text { 2014 at the earliest }\end{array}$ \\
\hline
\end{tabular}

Against the bedrock provided by the CGC, it is no surprise that the introduction of the SC in the UK in July 2010 was closely followed across the world. The CGC provides a detailed, well-tested and well-regarded route map against which the SC was to be compared. ${ }^{25}$ Regardless of the criticisms level at it, "the depth of compliance and quality of explanation are the milestones [of the CGCs overall] effectiveness," ${ }^{26}$ but the same cannot be said of the SC. In sharp contrast, its evolvement to date has been dissimilar to that of the CGC. The level of compliance and poor quality of explanation to date are indicative of its ineffectiveness. The course it has taken is similar to steering a car on a road with no clear destination in sight. It is like taking, to use the words of the 80s band Talking Heads' song 'a road to nowhere.'

\section{The alleged success}

More than four years have passed since the SC was published and despite the FRC's efforts to sell a 'success story', ${ }^{27}$ there are serious questions about its effectiveness. It seems that its hits are substantially fewer than its misses. I endeavour to set out the latter below.

First, it appears that, to date, even according to the FRC's own reports, the SC has not impacted on the quality of engagement ${ }^{28}$ (now characterized by the FRC as an

\footnotetext{
${ }^{25}$ The value of a constructive and meaningful dialogue between institutional shareholders and companies has traditionally underscored the UK Corporate Governance Code that is founded on a "mutual understanding of objectives". In the SC, the FRC sets out what it calls "a number of areas of good practice to which the FRC believes institutional investors should aspire." See, FRC's website at:

https://www.frc.org.uk/Our-Work/Codes-Standards/Corporate-governance/UK-Stewardship-Code.aspx (accessed 1 May 2014). The FRC hoped that the new SC would create a stronger link between the governance and investment process and that it: "expects the content of the Code to evolve over time to reflect developments in good engagement practice, in the structure and operation of the market, and the broader regulatory framework,...". See, FRC, The UK Stewardship Code (July 2010$), 3$. https://www.frc.org.uk/Our-Work/Publications/Corporate-Governance/The-UK-Stewardship-Code.pdf (accessed 30 April 2014). ${ }^{26}$ Sir Roger Carr 'Adherence to the Spirit' in 20th Anniversary of the UK Corporate Governance Code Financial Reporting Council (London, 2012), 16.

${ }^{27}$ For example, according to DBIS "evidence suggests encouraging progress in the volume and quality of stewardship and engagement, and in reporting on stewardship activity" DBIS, Building a Culture of Long-Term Equity Investment:

Implementation of the Kay Review Progress Report (Department for Business, Innovation and Skills, October 2014), 7 . Further, in the words of the FRC: "This level of take-up indicates that the concept of stewardship is being taken seriously. Importantly there has been a wide base of support for the Stewardship Code including from both large and small institutional investors." FRC, Developments in Corporate Governance: The impact and implementation of the UK Corporate Governance and Stewardship Codes (December 2011), 20. Available at:

https://www.frc.org.uk/Our-Work/Publications/Corporate-Governance/Developments-in-Corporate-Governance-2011-Theimpa.aspx (accessed 19 March 2014).

${ }^{28}$ FRC, Impact of the Codes (December 2011), 5 states: “As to whether the Stewardship Code has yet had an impact on the quality of engagement, there are mixed signals. Many companies the FRC spoke to said that they had not seen any notable increase in the number of investors wishing to engage with them particularly outside the upper reaches of the FTSE Index - but others said that where engagement took place the quality had improved, with investors showing an interest in a wider range of governance, capital raising and strategic issues." (my emphasis). Similarly, DBIS, A Long Term Focus for Corporate Britain (October 2010), 20, states that "not enough effective engagement is taking place on issues of substance" and that "Some chairmen have complained that too much engagement takes the form of discussion about quantitative analysis rather than business fundamentals." (my emphasis).
} 
"engagement deficit"29), nor has it made any discernable impact on the attitude of companies. ${ }^{30}$ Secondly, it is equally important to dispel the myth about the level of compliance with the SC. The FRC has repeatedly held that the SC enjoys a "multiinvestor base of support" "31 that has led to "the concept of stewardship finally being taken seriously" and a "rapid increase in adherence to the $\mathrm{SC}^{\text {" } 32}$ both in the UK and abroad. These expressions of support should be taken with a pinch of salt. According to its own report, the FRCs confidence is based on the number of signatories to the SC, which reached almost 300 in October $2013 .{ }^{33}$ However, whether or not the number of signatories translates into compliance is another matter entirely. Ultimately, institutional investors' apparent commitment to the SC could be guided by a 'fear of the alternative' - i.e., a regulation-dominated approach which is seen as carrying with it the loss of rights (see Section C below). Such a fear is well founded if the EU's proposals to regulate shareholder engagement are to go ahead as planned. ${ }^{34}$ Even where compliance is not based on fear, in the investors' world, appearances matter. Institutional shareholders may find it is important to show support for a trendy concept in order to avoid criticism and show they are indeed listening. Moreover, it is cheaper to comply (and easier, considering how lax the SC's requirements are) ${ }^{35}$ than to explain and it reflects well on institutional investors even if no meaningful change occurs. ${ }^{36}$ In short, it pays off.

Third, it appears that the SC has not impacted positively on the quality of disclosures made in compliance statements/responses either. In 2011, a Steering Group chaired by the FRC's Chief Executive agreed to oversee the development of a questionnaire designed - at least in theory - to test the effectiveness of the SC. ${ }^{37}$ At a first glance,

\footnotetext{
${ }^{29}$ FRC, Annual Report and Accounts 2013/14 (2014), 16 available at https://www.frc.org.uk/Our-Work/Publications/FRCBoard/FRC-Annual-Report-and-Accounts-2013-14-print-versi.pdf (accessed 6 November 2014).

${ }^{30}$ The DBIS' report A Long Term Focus for Corporate Britain (October 2010), 20 states that: "some investors feel that boards do not take engagement seriously". The FRC, Impact of the Codes (December 2011), 24 states similarly that: "Shareholder views on the attitude of companies are similarly mixed. There is anecdotal evidence that some companies are making a greater effort to engage, with more chairmen taking the initiative of contacting key shareholders. Yet there is also criticism that some companies are becoming less responsive to shareholder votes and more inclined to ignore a significant 'oppose' vote as long as they win majority support. Insofar as the Stewardship Code aims to promote better relations between companies and their shareholders, this reaction is counterproductive and ultimately risks undermining the concept of "comply or explain'."

${ }^{31}$ Former FRC Chairman Baroness Hogg (19 October 2010). Available at:

https://www.frc.org.uk/News-and-Events/FRC-Press/Press/2010/October/FRC-Showcases-Investor-Backing-for-Stewardship-

Cod.aspx (accessed 12 April 2014).

${ }^{32}$ Ibid.

${ }^{33}$ FRC, Developments in Corporate Governance 2013 (December 2013), 1 and 4.

${ }^{34}$ Proposal for a Directive of the European Parliament and of the Council Amending Directive 2007/36/Ec as Regards the Encouragement of Long-Term Shareholder Engagement and Directive 2013/34/EU as Regards Certain Elements of the Corporate Governance Statement, COM/2014/0213 final (April 2014).

${ }^{35}$ This relaxed approach is well-illustrated in a speech by Lindsay Tomlinson, (then) the Chairman of the NAPF provided in March 2011 at the annual NAPF Investment Conference in Edinburgh: "How should the end investors, the beneficial owners, such as pension funds respond? My view is that they should take note of the Code, should sign up to it themselves and should expect to hold their fund managers to account over their own Stewardship Code Activities. For a pension fund it's not a very demanding task, but it's a significant step in tightening the ratchet on corporate governance." See, http://www.napf.co.uk/Conferences_and_Seminars/Investment_Conference.aspx (accessed 30 April 2014).

${ }^{36}$ Drawing on explanations from behavioural finance this seems to make sense. Morck, for example, explains, in the context of independent directors that: "Asch (1951) shows that people tend to go along with a "group consensus" - even one rigged to be obviously wrong. Kahneman and Tversky (2000) summarize a large literature that shows people's decisions depend critically on how their options are "framed". Even truly independent directors may feel a need to conform to a group consensus." See, R Morck, 'Behavioral Finance in Corporate Governance -Independent Directors and Non-Executive Chairs' (11 April 2007), 16 available at: http://papers.ssrn.com/sol3/papers.cfm?abstract_id=979880 (accessed 30 April 2014). Another interesting example that Morck draws on is that of ...information cascades (Banerjee, 1992; Bikhchandi, Hirshleifer, and Welch, 1992) “....which occur when people rationally imitate a player who has already paid to become informed, rather than pay to become informed themselves. Thus, we presume more crowded restaurants have better food, and praise oeuvres of already lauded modern artists." Ibid, 17.

${ }^{37}$ The questionnaire gathered responses from 41 asset managers, 7 asset owners and 2 service providers. Investment Management Association (IMA) Adherence to the FRC's Stewardship Code at 30 September 2010 (May 2011). Available at: http://www.investmentfunds.org.uk/research/stewardship-survey/ (accessed 12 April 2014). A similar report was published in 2013, which again, purportedly showed 'progress'. See, Adherence to the FRC's Stewardship Code at 30 September 2012 (June 2013).
} 
the questionnaire's major findings seemed positive and encouraging. Answers to it reflected widespread adherence by UK institutional investors; increase in the number of institutional investors voting; increased disclosure of voting records; and an increase in public statements on adherence to the SC. However, the questionnaire's results are less convincing in the face of some undeniable facts. Evidence suggests that, overall, the SC has not been successful in eliciting meaningful shareholder engagement. Rather, it seems to be trapped in the middle of a vicious circle: on the one hand, it has proven to be an insufficient tool to tackle the structural barriers institutional investors face if they were to be effective 'stewards'. On the other hand, it is precisely the presence of these barriers - and the SC's failure to address them that renders it ineffective.

It is generally accepted that there are limits to what the 'comply or explain' approach can achieve as its effectiveness depends on a number of factors. ${ }^{38}$ When it comes to its ability to enhance stewardship, the number of shareholders that engage in monitoring activities and the quality of explanations given in the event of noncompliance are particularly relevant and deeply correlated. Explanations should be sufficiently detailed and provide meaningful information so as to present an accurate picture of the shareholders' positions on relevant issues. In reality, however, the SC fails to achieve this. Institutional shareholders have little impact on the decisions made by investee companies, usually remain at a distance from substantive issues dealt with by management, and/or for whatever other reasons generally have no interest in getting involved in monitoring activities (e.g., because they are foreign). ${ }^{39}$ Furthermore, there seems to be a recurring disappointment that too many explanations by institutional investors are characterized as "boilerplate" and "do not reflect a true engagement with the issues at hand." FRC now admits that "[M]any statements on the Stewardship Code give little insight into investors' actual practices."41

The same can be said about the statements regarding adherence to the SC and its principles, which seem to fall in the 'tick-the-box' category. ${ }^{42}$ Further, the quality of reporting is, even according to the FRC, variable. ${ }^{43} \mathrm{Few}$ statements meet the FRC's expectations and more often than not fail to provide detailed explanations of what adherence to the SC entails and their positions, strategies and policies on relevant issues (such as the use of proxy voting agencies). ${ }^{44}$ For example, "many statements around the principle on collective engagement focused on membership of collective

\footnotetext{
${ }^{38}$ See, for example, M Moore, 'Whispering Sweet Nothings: The Limitations of Informal Conformance in UK Corporate Governance' (2009) 9 Journal of Corporate Law Studies 77.

${ }^{39}$ Adding to these problems is the fact that "the quality and quantity of shareholder engagement is very difficult to measure as so much of it necessarily takes place in a confidential environment, restricting information about practice and consequences." See DBIS: A long Term Focus for Corporate Britain: Summary of Responses (March 2011), 20.

${ }^{40} \mathrm{O}$ the "we consider this to be in the best interests of the company and its shareholders" type.

${ }^{41}$ Baroness Hogg, Former FRC Chairman, FRC, News Section PN11 (19 December 2013) at: https://www.frc.org.uk/News-andEvents/FRC-Press/Press/2013/December/FRC-encourages-better-comply-or-explain-disclosure.aspx (accessed 22 April 2014). ${ }^{42}$ Some have also complained about the lack of accessibility to these statements. "The FRC website provides a link to all signatory statements, but these are not necessarily easily accessible via another route." FRC, Developments in Corporate Governance: The impact and implementation of the UK Corporate Governance and Stewardship Codes (December 2011), 2122. Further, "a review carried out by the FRC found that over $40 \%$ of statements provided no contact information whatsoever, and that many others did not include either an email address or telephone number for the contact." Ibid, 22. The FRC has therefore called for each supporting institution to name an individual who is the main contact in relation to stewardship matters. ${ }^{43}$ FRC, ibid, 12.

${ }^{44}$ As the FRC puts it: "The quality of reporting by Stewardship Code signatories remains variable. Nearly half of the signatories to the Code have not yet updated their public statements over a year after a revised edition of the Code took effect in October 2012. The FRC is considering mechanisms for ensuring that statements are complete and up to date, and possible sanctions if they are not." FRC, Developments in Corporate Governance 2013 (December 2013), 29.
} 
bodies," 45 but "while this is welcome, it skirts round the main reason for this principle, which is the need for investors to be able to join forces at critical moments to ensure that boards acknowledge and respond to their concerns."

\section{Why hasn't it worked?}

Investors are undoubtedly interested in deriving as much value as possible from their holdings. Thus, in theory it would make sense for them to engage in the level of monitoring that would allow them to identify and correct any under-performance by management that could impact on their returns. However, in practice this is not straightforward at all. In fact, shareholders most commonly resort to selling their shares as the preferred method of indicating their discontent, thereby taking no part in the actual exercise of ownership responsibilities. ${ }^{47}$

Some institutional investors are rather passive in nature and tend to be generally disinterested and inefficient in monitoring their companies. Further, "the characteristics of the modern investment management practices make it extremely hard for an active, long-term ownership mind-set to take hold, which hinders shareholder engagement." ${ }^{48}$ As Kay pointed out, the extent to which the SC has contributed to solve this problem is unclear. ${ }^{49}$ But it is argued below that the reasons for its lack of success are somewhat clearer.

\section{Speediness and Publicity Over Depth and Rigour}

Caught up in the whirlwind that characterized the period following the crisis the FRC unreservedly adopted the Walker Review's recommendations aimed at eliciting "...more vigorous scrutiny and engagement by major investors...". ${ }^{50}$ Unfortunately, this resulted in a situation where principles and practices were embedded in the SC without testing them first, thus having less predictability as to whether they would be successful in eliciting the desired conducts. Arguably, this was necessary and that it is better to have the SC we have today than nothing at all. However, I would be very careful to adopt this position. With hindsight, it seems that significant time and resources could have been saved if the FRC had taken a step back to engage in deeper reflection on these issues instead of falling easy prey to outside pressures. As Chiu points out, the danger of the FRC's strategy is that "shareholders' stewardship could ultimately become a lightweight and a mere rhetoric, not actually expressing the indirect stakes and social concerns as a consistent for governance." ${ }^{, 51}$ The sad truth is that the FRC may have missed a unique opportunity to go deeper and design principles and practices that could successfully change behaviours in the long run.

\footnotetext{
${ }^{45}$ FRC, Developments in Corporate Governance (December 2011), 21-22. Taking 2CG Limited as an example again, in their UK Stewardship Code Disclosure Statement they acknowledge the possibility of collective action but with no specificity and without saying when they would feel such action would be appropriate. Available at: http://www.2cg.com/docs/prospectus/stewardship.pdf (accessed 12 April 2014).

${ }^{46}$ FRC, ibid.

${ }^{47}$ S CY Wong, 'Why Stewardship is Proving Elusive for Institutional Investors' Northwestern Law and Economics Research Paper No. 10-28, (2010) Butterworths Journal of International Banking and Financial Law 406, 408.

${ }^{48}$ Ibid, 406.

${ }^{49}$ For a detailed analysis see J Kay, The Kay Review of UK Equity Markets and Long-Term Decision Making (July 2012 ), 13.

${ }^{50}$ Lord Myners, 'Association of Investment Companies'(April 2009), Available at:

http://webarchive.nationalarchives.gov.uk/20091207163737/http://hm-treasury.gov.uk/speech_fsst_210409.htm in Roach, supra n $4,467$.

${ }^{51}$ See, I H-Y Chiu, 'Institutional Shareholders as Stewards: Toward a New Conception of Corporate Governance' (2012) 6 Brooklyn Journal of Corporate, Financial \& Commercial Law 387, 431.
} 
One of the SC's most evident flaws is its failure to define the meaning of stewardship. ${ }^{52}$ This has given rise to general confusion and misunderstanding ${ }^{53}$ since different players have varying interpretations of the concept. Furthermore, the fact that there is no clear definition as to what is expected from mangers and asset owners in terms of their respective roles and responsibilities, has had impacted directly on the effectiveness of the SC. Arguably one of the functions of a code would be precisely to provide clarification in this type of situation. ${ }^{54}$ However, due to the hastiness involved in its creation, the SC has blatantly failed to serve this function. Even later attempts to rectify this have failed miserably. In September 2012 the FRC added a new introductory part to the SC entitled 'Stewardship and the Code'. According to this new section:

1) "Stewardship aims to promote the long-term success of companies in such a way that the ultimate providers of capital also prosper. Effective stewardship benefits companies, investors and the economy as a whole.

2) In publicly listed companies responsibility for stewardship is shared. The primary responsibility rests with the board of the company, which oversees the actions of its management. Investors in the company also play an important role in holding the board to account for the fulfilment of its responsibilities. (...).",55

There are a number of problems with this definition. First, it is prima facie circular. By using the term stewardship to define what stewardship means it contributes little to clarifying the confusion and misunderstanding. Moreover, it seems to focus on explaining what stewardship aims to achieve, rather than articulating what shareholders' stewardship responsibilities are. Furthermore, the SC is unclear as to whom shareholders are accountable to ${ }^{56}$ This overall lack of clarity and ambiguity has led commentators to describe stewardship under the SC as ideologically weak: "if we cannot pinpoint for whom institutions should act as stewards, then it becomes difficult to judge the exercise of stewardship allowing institutions to dominate the definition of stewardship." 57 (my emphasis).

Additionally, it is unclear why the FRC did not resort to existing definitions of stewardship when it added the 'Stewardship and the Code' section in 2012. ${ }^{58}$ Overall,

\footnotetext{
${ }^{52}$ Reisberg noted this in 2010, supra n 4,133. In 2012 Professor Kay also addressed this. In the Kay Review he made 17 recommendations. The first one articulated that: "the Stewardship Code should be developed to incorporate a more expansive form of stewardship, focusing on strategic issues as well as questions of corporate governance." (The Kay Review, supra $\mathrm{n} 49$, 13).

${ }^{53}$ Even the FRC admitted this is the case. See FRC, Consultation Document: Revisions to the UK Stewardship Code (April 2012), 6. Available at:

https://www.frc.org.uk/getattachment/fa05e79c-22c6-4f8f-b5b3-2ab55ec41113/Consultation-Document-Revisions-to-the-UKStewards.aspx (accessed 13 April 2014).

54 The FRC stated "we are rewriting the introduction to provide a clearer articulation of the stewardship. That is the requirement of accountability all along the investment chain. We will also try to differentiate more clearly the roles played by asset owners and asset managers. We will also propose to strengthen the language in a number of areas: around conflicts of interest, acting together and the use of proxy voting agencies." Former FRC Chairman Baroness Hogg, ICGN Conference, (20 March 2012), 45 .

${ }^{55}$ See the SC (September 2012), 1.

${ }^{56}$ Commentators have argued that the SC statement that the board and investors share responsibility for stewardship is particularly dangerous as it may weaken accountability. See Comment Letter submitted to the FRC Consultation in July 2012 by Nyenrode, Nyenrode Corporate Governance Institute (12 July 2012).

${ }^{57}$ See, Chiu, supra n 51, 427.

${ }^{58}$ To give but one possible solution, according to the EU Corporate Governance Framework Green Paper (April 2011)

'shareholder engagement' is generally understood as "actively monitoring companies, engaging in a dialogue with the company's board, and using shareholder rights, including voting and cooperation with other shareholders, if need be to improve the
} 
it is questionable whether stewardship under the SC actually makes any contribution towards tackling the engagement deficit. In the end, how are institutional investors supposed to take the concept seriously when it is not even defined? When it speaks about them as if they were all the same kind of investors when they are clearly not? While it may be true that the SC has received wide recognition, ${ }^{59}$ and even calls for it to be replicated in other jurisdictions,${ }^{60}$ these expressions of support may be, in reality, hollow and meaningless: it is easy to support something without real implications. ${ }^{61}$

\section{Incorrect focus}

A fundamental, yet seemingly unanswered question remains; whether the SC "mistakenly concentrates monitoring in the hands of shareholders, where other stakeholders have greater incentives to monitor, thereby unnecessarily relegating the importance of other stakeholders?"62 Commentators have labelled this re-emphasis on shareholders as rather unimaginative and path-depending. ${ }^{63}$ Thus in this section I analyse the features that characterize share ownership nowadays and confront head-on the real issues that act as barriers to stewardship by shareholders. I then challenge the assumption that shareholder activism is a 'good thing'. I analyse the views of those who point to the risks it may carry with it (e.g. that it might incentivise micromanagement by institutional shareholders and create inefficient and undesired costs for companies). ${ }^{64}$

Effective engagement with investee companies - at least as currently understood requires the design and adoption of certain specific procedures. ${ }^{65}$ However,

governance of the investee company in the interests of long-term value creation." See, European Commission Green Paper; The EU Corporate Governance Framework 2011 (5 April 2011) European Commission; COM (2011), 164. Available at:

http://ec.europa.eu/internal_market/company/modern/corporate-governance-framework_en.htm (accessed 12 April 2014)

See also the definitions offered in Reisberg, supra n 4, 128. For example, the Oxford English Dictionary defines 'stewardship' as

"the act of taking care of or managing something, for example, property, an organization, money or valuable objects." In the

context of a company or of businesses more generally, Tomorrow's Company (2009) defines it as: "[. . . the active and responsible management of entrusted resources now and in the longer term, so as to hand them on in better condition."

59 As the FRC reports "As at the beginning of December 2013, the Stewardship Code had 290 signatories, a modest overall increase from 259 at the same point in 2012. 203 signatories are asset managers, 73 asset owners and 14 service providers." FRC, Developments in Corporate Governance 2013 (December 2013), 21.

Casting an eye on the UK's SC, the Securities Commission Malaysia and the Minority Shareholder Watchdog Group issued a joint consultation on 15 January 2014 for the introduction of 'The Malaysian Code for Institutional Shareholders'. The proposed code follows very closely the wording of the UK's SC and sets out guidance for institutional investors on "effective exercise of stewardship responsibilities towards the delivery of sustainable long-term value to the institutional investors' ultimate beneficiaries or clients." See, http://www.mia.org.my/new/1_tech_detail.asp?tid=3\&rid=1\&id=1269 and the Consultation Paper at: http://www.mswg.org.my/files/editor_files/file/MCII/JOINT-PUBLIC-CONSULTATION-PAPER-ON-MCII 150114.pdf (accessed 6 May 2014).

${ }^{60}$ Tan, supra $\mathrm{n} 15,210$.

${ }^{61}$ When this author presented an earlier version of this article in Tokyo in February 2013 he was approached by a member of the audience (who shall remain anonymous) who said she was entirely surprised to hear his criticisms of the SC as the perception in some Governmental Japanese departments was that the UK SC is a success story and that Japan should follow its developments closely. Indeed, a draft of the "Principles for Responsible Institutional Investors" (Japan's Stewardship Code): "To promote sustainable growth of companies through investment and dialogue" was published in late 2013, with the English version of the draft code published on 15 January 2014 and as of September 2014, 160 institutional investors had signed up to it. See, http://www.fsa.go.jp/en/news/pub.html (accessed 3 December 2014). See, M Orsagh, Shareholder Engagement: Bridging the Divide Between Boards and Investors' CFA Blog (26 March 2014) at: http://blogs.cfainstitute.org/marketintegrity/2014/03/26/shareholder-engagement-bridging-the-divide-between-boards-andinvestors/ (accessed 6 May 2014)

${ }^{62}$ See, Chiu, supra $\mathrm{n} 51,428$.

${ }^{63}$ C M Bruner, 'Power and Purpose in the “Anglo-American” Corporation' (2010) 50 Virginia Journal of International Law 329 and Chiu, supra n 51, 415-420.

64 Professor Bainbridge in his blog on 27 October 2010 available at:

http://www.professorbainbridge.com/professorbainbridgecom/2010/10/insane-institutional-investors-pick-nits.html (accessed 30 March 2014)

${ }^{65}$ Such as: (i) arrangements for monitoring investee companies; (ii) arrangements for meeting as appropriate with a company's Chairman or senior management; (iii) strategy for intervention where judged appropriate; and (iv) policy on voting and voting disclosure. See Walker, supra $\mathrm{n} 22$. 
impediments to shareholder engagement impose considerable limitations to the potential use of these mechanisms as corporate governance tools. Traditional impediments extend across a wide range of issues. To begin with, shareholders are deterred from engaging because of "the cost of engagement, the difficulty of valuing the return on engagement and the uncertainty of the outcome of engagement, ${ }^{66}$ including free rider behaviour." ${ }^{67}$ Other issues include collective action difficulties and agency problems between secondary institutional investors and fund managers (including lack of effective incentives for fund managers). ${ }^{68}$

Moreover, the nature and landscape of modern UK share ownership is diverse and constantly evolving, which further challenges effective investor engagement. This has lead Gilson and Gordon to claim that the Berle-Means understanding of dispersed shareholder ownership no longer applies, and that we should now be thinking in terms of "'agency capitalism' an ownership structure in which agents hold shares for beneficial owners". ${ }^{69}$ The SC does not account for these impediments to engagement and the landscape of modern shareholder ownership. What is worse, it does not even seem to have picked up on them. ${ }^{70}$ Borrowing Wong's account of these structural deficiencies, let us look more closely at this situation and its impact on the engagement deficit.

\section{(a) Are shareholders 'too far' from companies?}

The first barrier that Wong identifies is the "lengthening of the share ownership chain." Indeed, the chain of intermediaries from the ultimate beneficial interests to the company "has become longer and much more complicated than the traditional theoretical model would suggest." ${ }^{72}$ The increasing degree of specialization of functions and roles along the intermediary chain has prompted the appearance of diverse new actors ${ }^{73}$ that put the ultimate holders of beneficial interests at a much further distance from the companies' activities. This weakens the 'owner' mind-set and "lessens the sense of accountability between the ultimate investor and the investee company." "74 Gilson and Gordon believe this leads to a 'rational reticence' on the part of the institutional investors, meaning the very nature of their business model does not allow for sufficient monitoring and engagement with portfolio companies to provide meaningful interaction with corporate governance. ${ }^{75} \mathrm{EU}$ proposals on shareholder engagement suggest that the only way to deal with this is through

\footnotetext{
${ }^{66}$ e.g., some funds compete on costs basis - requiring them to engage in activism raises costs, with no clear advantage.

${ }^{67}$ See, European Commission Green Paper; The EU Corporate Governance Framework 2011 (5 April 2011) European Commission; COM (2011), 164.

${ }^{68}$ On this issue see for example, Wong, supra $\mathrm{n} 47,408$ and $\mathrm{J}$ Rhee, 'Short-Termism of Institutional Investors and the Double Agency Problem' (9 May 2013) HLS Forum on Corporate Governance and Financial Regulation. Available at:

https://blogs.law.harvard.edu/corpgov/2013/05/09/short-termism-of-institutional-investors-and-the-double-agency-problem/ (accessed 12 April 2014).

${ }^{69}$ R Gilson and J Gordon, 'The Agency Costs of Agency Capitalism: Activist Investors and the Revaluation of Governance Rights' 2013 Columbia Law Review 863, 865.

${ }^{70}$ Wong points out that "Kay omitted one crucial reform that would materially effect of the achievability of several of his key recommendations: shortening the chain of intermediaries, eliminating the use of short-term performance metrics for asset managers, and adopting more concentrated portfolios." See S CY Wong, 'The Missing Reform in the Kay Review' (26 July 2012). Available at: http://ssrn.com/abstract=2119415 (accessed 13 April 2014). Although the Kay Review recommends that 'companies should try to disengage from the process of managing short-term earnings expectations and announcements' (see Kay Review, supra n 49, 13 (recommendation 6)), I agree that it can probably only be resolved by a structural reform of the industry itself.

${ }^{71}$ See, Wong, supra $\mathrm{n} 47,406$.

${ }^{72}$ DBIS: A long Term Focus for Corporate Britain: A Call For Evidence (October 2010), para 4.4.

${ }_{73}$ e.g., investment consultants, 'funds of funds', external asset managers and others.

74 See, Wong, supra n 47, 407.

75 Gilson and Gordon, supra n 69, 867.
} 
regulation that requires the public disclosure of strategy, monitoring, engagement and dialogue with investee companies along the investment chain. ${ }^{76}$

\section{(b) Short-termism vs. Activism}

Modern share ownership is characterized by a growing culture of short-termism, which, in turn, can be attributed to two interrelated issues: (1) the difficulty of measuring a company's performance against its long-term strategy; and (2) the need to evaluate the performance of asset managers over short periods of time. These two factors give rise to a vicious circle: shareholders focus on short-term indicators (e.g., quarterly reports and share prices) to evaluate the performance of many asset managers, who, in return, focus on short-term returns at the expense of those over the long-term. This problem is not new. The Myners Review in 2001 suggested that "external pension fund managers, unit trust and unit-linked managers are under constant and intense pressure to maximize current performance. The current quarter is what matters, perhaps the next quarter, certainly not next year's equivalent quarter." 77 Indeed, intermediaries were criticised by the Kay Review "for excessive trading on the basis of short-term share movements, rather than investing for the long-term.",78

Wong suggests further that "inappropriate performance metrics and financial arrangements that promote trading and short-term returns" $" 79$ act as another barrier to stewardship. For the purposes of the SC and its intended goals this is very problematic as it changes the way investors look at companies. Interest in the company is limited to what can be achieved within a specific period of time; a visible point on the horizon. Incentivising engagement seems to be an uphill battle where long-term performance has become less relevant as investors place more value on the ability to mitigate risk and the freedom to detach themselves from an underperforming company. And, as Gilson and Gordon persuasively point out in relation to institutional investors, "a successful intervention will produce benefits enjoyed by all shareholders, including the mutual funds competitors. But a shared gain, unlike the private gain of a successful trade, provides little competitive advantage to the proactive investment manager whose portfolio products are chosen in comparison to competitors offering similar products or services". 80

\section{(c) Excessive Diversification, Insufficient Incentives}

The lengthening shareholding chain and the focus on short-term returns accompanied by shorter holding periods are commonly associated with modern management strategies. 'Diversification', in particular, is one that has become very popular and has had a great impact on shareholder engagement. Many institutional investors use techniques to handle risk which have caused 'excessive diversification'. ${ }^{81}$ Equity portfolios comprise of numerous shares ${ }^{82}$ and this, inevitably, carries with it a reduced

\footnotetext{
${ }^{76}$ See, Proposal for a Directive of the European Parliament and of the Council Amending Directive 2007/36/Ec as Regards the Encouragement of Long-Term Shareholder Engagement and Directive 2013/34/EU as Regards Certain Elements of the Corporate Governance Statement (April 2014).

${ }^{77}$ See, T. Goldings, The City: Inside the Great Expectation Machine, Financial Times and Prentice Hall (2002) in B Richardson, Socially Responsible Investment Law: Regulating the Unseen Polluters, Oxford University Press (2008), 138.

${ }^{78}$ See, Kay Review, supra n 49, para 7.16.

${ }^{79}$ See, Wong, supra n 47, 406.

${ }^{80}$ Gilson and Gordon, supra n 69, 890.

${ }^{81}$ On which see more, Kay Review, supra n 49, para 6.12.

${ }^{82}$ See, Wong, supra n 47, 406.
} 
interest in monitoring individual companies' activities. Where 'risk management' is the driving force, commitment with the future of a particular company could be deemed a waste of time. ${ }^{83}$

The engagement deficit that accompanies excessive diversification is also related to the fact that the resources (including time and effort) that investors are able to devote to monitoring a specific company are finite. For example, the general meetings for most companies in the UK are concentrated over a short or same period of time (See Figure 1 below). The effect is, as the FRC itself puts it, to create yet "[A]nother barrier to effective engagement." 84 Indeed, institutional investors with diversified portfolios may have not only little incentives but also limited resources to get fully immersed in monitoring the issues faced by each company and make constructive contributions in each meeting held. In a 2012 review the European Securities Markets Authority (ESMA) noted that:

"investors appear to prioritise the resources they have available based on the impact that the vote may have on portfolio performance e.g. taking into account the size of the stake they have in the firm, the performance of the firm (where a relatively poor performance increases the need for monitoring), or the potential value implication of the proposal." 85

But even where monitoring does happen, it is common to find that the less qualified and more junior staff are often appointed to take over corporate governance tasks where excessive diversification accord investors smaller stakes in companies. ${ }^{86}$

Figure 1 Concentration of General Meetings Over Time.

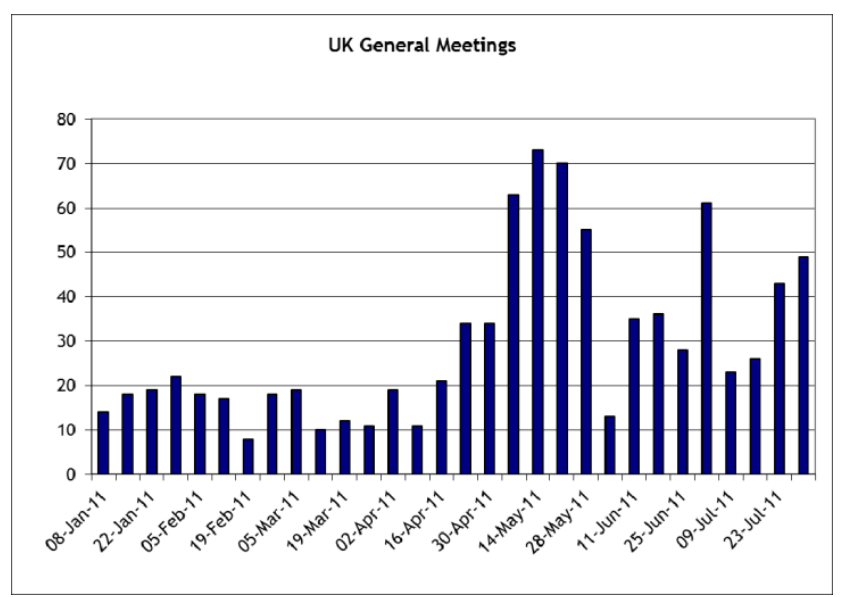

Source: Manifest - The Proxy Voting Agency ${ }^{87}$

(d) Unclear Duties, Wrong Expectations

\footnotetext{
${ }^{83}$ As the former UK City Minister Lord Myners puts it: "investment management today is characterised by portfolios with high diversification and low exhibited stock conviction." See, Lord Myners in Wong, supra n 47, 407.

${ }^{84}$ FRC, Impact of the Codes (December 2011), 28.

${ }^{85}$ European Securities and Markets Authority (ESMA), Discussion Paper, An Overview of the Proxy Advisory Industry.

Considerations on Possible Policy Options (22 March 2012),19, in M. Glenister, 'Will the Kay Review have a long-term impact on the investment chain?' My Investor Circle, Peer Network Review, Corporate Governance (April 2013).

${ }^{86} \mathrm{M}$ Glenister, ibid.

${ }^{87}$ As adapted by the FRC, Impact of the Codes (December 2011), 28.
} 
It is clear that the combination of investor preferences and behaviours and management strategies add significant barriers to shareholder engagement. However, the roots of the problem may lie elsewhere. In order to unveil this, we must look at the core of the relationship between the ultimate beneficial owner and the other players in the management chain. As was pointed out above (under (a)), across the investment chain it is generally expected that a managers' focus will be on furthering their clients' economic interests, rather than non-financial ones. Shareholder engagement, if any, "takes the form of discussions about quantitative analysis rather than business fundamentals." 88

According to Wong, this results from a "misguided interpretation of fiduciary duty that accords excessive deference to quantifiable data at the expense of qualitative factors. ${ }^{89}$ This may be skewing the investment management practice in the wrong direction. ${ }^{90}$ Indeed, as the (former) FRC Chairman noted, investment managers should be expected to act not only as "forecasters who take a view of the share price against expected earnings", ${ }^{11}$ but also as guardians of a company's long-term, sustainable growth. ${ }^{92}$ These are fundamental issues that have a profound impact on the dynamics of the different relationships across the investment chain, and thus on corporate governance. Clarifying the content and reach of these fiduciary duties could, in turn, lead to a reallocation of responsibilities, redefined expectations, a rethinking of strategies and techniques and an adjustment in the role of each player accordingly.

\section{(e)The problem with passive funds}

As Wong suggests, passive investing ${ }^{93}$ "precludes trading in and out of individual stocks and seeks long-term gains in the broad equity market." ${ }^{94}$ Accordingly, in theory at least, passive funds and stewardship should go hand in hand. However, most passive funds do not allocate resources to proxy voting, scarcely promote any real engagement and run afoul of corporate governance best practices (and some even appear to harm stewardship). ${ }^{95}$ The question is then to what extent can these funds justify not complying with the SC and how realistic is it to ask them to explain their business model?

\footnotetext{
${ }^{88}$ DBIS, A Long-Term Focus for Corporate Britain: A Call for Evidence (October 2010), 20. Available at: https://www.gov.uk/government/uploads/system/uploads/attachment_data/file/31563/10-1225-long-term-focus-corporatebritain.pdf (accessed 17 March 2014)

${ }^{89}$ Wong, supra $\mathrm{n} 47,406$.

${ }^{90}$ As Kay importantly noted: "some pension fund trustees equated their fiduciary responsibilities with a narrow interpretation of the interests of their beneficiaries which focused on maximising financial returns over a short timescale and prevented the consideration of longer term factors which might impact on company performance, including questions of sustainability or environmental and social impact." See, Kay Review, supra n 49, para 9.20. The Final Report also recommended that "regulatory authorities at EU and domestic level should apply fiduciary standards to all relationships in the investment chain' (...) and that "the Law Commission should be asked to review the legal concept of fiduciary duty as applied to investment to address uncertainties and misunderstandings on the part of trustees and their advisers." See ibid, 13.

${ }^{91}$ Former FRC Chairman Baroness Hogg, ICGN Conference, (20 March 2012), 2-3.

${ }^{92}$ She continued by stating that "(Investment Managers) should have a rounded view of the companies in which they invest, its business model, risk management and the strengths and weaknesses of its board and management. These issues are all important factors in the ability of companies to generate sustainable value.” Former FRC Chairman Baroness Hogg, ICGN Conference, (20 March 2012),2-3.

${ }^{93}$ Passive fund is "A collective fund that tracks rather than trying to beat the index by investing in companies in accordance with the constituents of an index. The managers of the fund have far lower expenses, and the charges to investors are lower than for active funds. Active funds aim to outperform the market average by seeking out stocks that will provide superior total return using research and analysis." See, http://www.finance-glossary.com/define/passive-fund/1651/0/P (accessed 30 April 2014).

${ }^{94}$ See, Wong, supra n 47, 409.

${ }_{95}$ Ibid.
} 


\section{(f) Did We Miss Something? Ah Yes, Foreign Investors}

The SC seems oblivious to the fact that shareholders who are not the SC's main targets ${ }^{96}$ now collectively dominate UK share registers. Nowadays, ownership of UKlisted companies looks something like the following: ${ }^{97}$

- $53.2 \%$ beneficially owned by foreign investors

- $10.7 \%$ owned by UK individuals

- $9.6 \%$ owned by unit trusts

- $6.6 \%$ owned by other financial institutions

- $6.2 \%$ owned by insurance companies

- $4.6 \%$ owned by pension funds

Evidently, this large presence of overseas shareholders in the UK equity market makes them key players in the corporate governance system and central subjects of the SC. ${ }^{98}$ Any difficulties companies face associated with communicating with shareholders are exacerbated with respect to non-UK ones. They bring additional challenges to the table since they act very differently to their UK counterparts: ${ }^{99}$ the former are often mainly interested in obtaining a high return for their investment and do not want to be engaged in any monitoring activities. ${ }^{100}$ Smerdon identifies the danger of this behaviour when he notes that "one has to fear that the ability of huge [Russian] mining companies essentially controlled and operated outside the UK to ignore UK shareholders whilst enjoying the advantages of a London listing and recognition on a FTSE Index (...) is an abuse of governance and especially an abuse of the UK Stewardship Code."101

For all of these reasons, the FRC should have been particularly concerned with the task of devising incentives to elicit engagement by foreign shareholders ${ }^{102}$ Notwithstanding the above, the FRC's campaign to sell the SC as the ultimate tool to tackle the 'foreign investor' problem has remained unfettered. In many occasions it has made (misleading at best) statements regarding support for the SC from a 'wide range' of foreign investors. In 2010, the (former) FRC Chairman Baroness Hogg confidently stated that "the SC has attracted high calibre support from institutional investors, including international investors. This shows that the principle of stewardship, and our method of delivery through the market, resonates broadly outside the UK." ${ }^{103}$ However, the reality is that no more than a few foreign investors

\footnotetext{
${ }^{96}$ Primarily overseas investors, hedge funds and private individuals.

${ }^{97}$ Office for National Statistics, Statistical Bulletin: Ownership of UK Quoted Shares 2012 (September 2013). Available at: http://www.ons.gov.uk/ons/dcp171778_327674.pdf (accessed 19 March 2014). By the 1980s share ownership in the UK was dominated by domestic institutional shareholders. Individual ownership by UK investors (as opposed to ownership by, eg insurance companies, pension funds and banks) has significantly fallen (54\% in 1963).

${ }^{98}$ Conversely, the UK constitutes a relatively small market for many foreign investors in terms of their percentage of their invested assets - which further hinders engagement. See A Reisberg, 'The Notion of Stewardship from a Company Law Perspective. Re-defined and re-assessed in light of the recent financial crisis?' (2011) 18 Journal of Financial Crime $126,137$. ${ }^{99}$ For example, in a 2012 review the European Securities Markets Authority (ESMA) noted that "clients were more inclined to monitor recommendations made for domestic investee firms. The regulators view is that investors feel they have the knowledge to better steward shareholdings in their own domicile because they have greater access to and a better grasp of information about the underlying firm." See, M Glenister, 'Will the Kay Review have a long-term impact on the investment chain?' My Investor Circle, Peer Network Review, Corporate Governance, (5 April 2013).

${ }^{100}$ Some commentators, nonetheless, argue that long-term shareholders, both domestic and foreign, have similar interests and thus can be approached in the same way.

${ }^{101}$ R Smerdon, 'An abuse of the Stewardship Code?' Governance (February 2013) 10, 12.

${ }^{102}$ See also, Kay Review, supra n 49, 10 and 29.

${ }^{103}$ Former FRC Chairman Baroness Hogg (19 October 2010). Available at:

https://www.frc.org.uk/News-and-Events/FRC-Press/Press/2010/October/FRC-Showcases-Investor-Backing-for-StewardshipCod.aspx (accessed 19 March 2014).
} 
have actually signed it. Support, in other words, does not always translate to or equal adherence (i.e. one can submit a letter of support but still not sign the SC). Foreign investors' support for the SC appears to be another hollow demonstration that is not backed by any tangible evidence. For example, in December 2011 the FRC stated in its own report that:

\begin{abstract}
"It also requires further encouragement to overseas shareholders to become involved. In the coming year the FRC will, for its part, continue its effort to promote the concept of stewardship internationally. It is encouraging to see stewardship codes and principles being adopted in other markets, including most recently the newly revised Singapore Code of Corporate Governance, which may provide a useful impetus to its sovereign wealth funds. ${ }^{, 104}$ (my emphasis).
\end{abstract}

However, it is not clear what efforts were subsequently taken or in what way the FRC has encouraged or "promoted the concept of stewardship internationally". When the FRC published the second version of the SC in September 2012, it seems to have made it less likely, not more likely, that foreign investors will be involved in the SC when it stated that:

"Overseas investors who follow other national or international codes that have similar objectives should not feel the application of the Code duplicates or confuses their responsibilities. Disclosures made in respect of those standards can also be used to demonstrate the extent to which they have complied with the Code." ${ }^{\prime 05}$ (my emphasis).

At a European level this issue has not gone unnoticed. The European Commission have recently published proposals stating that, "only EU action can ensure that institutional investors and asset managers, but also intermediaries and proxy advisors from other Member States, are subject to appropriate transparency and engagement rules". ${ }^{106}$ If the proposals are adopted, such EU action will mean regulation to ensure intermediaries transmit voting information from foreign shareholders to the relevant company, with infringements to be subject to penalties. ${ }^{107}$

\title{
(g) The Alternative Option(s) Argument as a Weak Justification
}

Shareholder' continuous and enthusiastic support for the SC should come as no surprise. In the end, the alternative - regulation - is something that both UK and foreign shareholders want to avoid at all costs. The 'comply and explain' approach may represent some inconveniences to shareholders but it is overwhelmingly

\footnotetext{
${ }^{104}$ FRC, Developments in Corporate Governance: The impact and implementation of the UK Corporate Governance and Stewardship Codes (December 2011), 27. Available at:

https://www.frc.org.uk/Our-Work/Publications/Corporate-Governance/Developments-in-Corporate-Governance-2011-Theimpa.aspx (accessed 17 March 2014).

${ }^{105}$ FRC, Stewardship Code (September 2012), Application of the Code, para 9. This seems to concede to overseas investors, who expressed their concern upon the publication of the first version of the SC, that applying its requirements would duplicate their responsibilities.

${ }^{106}$ Proposal for a Directive of the European Parliament and of the Council Amending Directive 2007/36/EC as Regards the Encouragement of Long-Term Shareholder Engagement and Directive 2013/34/EU as Regards Certain Elements of the Corporate Governance Statement (April 2014), 3.

107 Ibid , Proposal 22
} 
preferred to legalistic and prescriptive approaches that could replace it if shareholder engagement is not demonstrated. ${ }^{108}$ The sad truth, however, is that this 'Alternative Option(s) Argument' is a rather weak justification for making the case that: (a) the SC is needed; and (b) that it is actually working. If anything, this is an indication of just how thin is the case for selling the SC and the need to adhere to it. Even more worrying, nonetheless, is the admission that the FRC must convince that the SC is a success story:

"When we come to write our annual monitoring review at the end of the year, we will need to show this change is at least getting seriously under way, that investment firms are taking a more joined up view and that this is showing through in a more insightful dialogue with companies.

If we cannot show this we will look very weak vis-à-vis Brussels just when the Commission will be putting together its definitive package on governance and shareholder rights." ${ }^{109}$ (my emphasis).

In any event, time appears to be running out in the hope of avoiding regulation in light of the EC's 2014 proposals for regulating shareholder engagement in the EU. ${ }^{110}$

\section{(h) The question that wasn't asked: Is Shareholder Activism a 'Good Thing'?}

According to Heineman, the SC is "the most detailed attempt to date to give institutional and regulatory form to the belief that shareholders are part of the solution, not part of the problem, and that they have not just a right, but a duty, to engage with the companies in which they invest". ${ }^{111}$ That said, the SC attempts to overturn the trend amongst institutional shareholders who prior to the crisis were, in Cheffins words "relaxed about banks using leverage to pursue high returns on equity, tended to deride cautious management and applied pressure for high dividends and share buybacks that depleted capital." 112 This evidently presupposes that "shareholder activism is a 'good thing'"113 - but is it really? The desirability of shareholder activism should not be taken as a given. ${ }^{114}$ Shareholder activism comes in cycles: "when things are going well, shareholders' voice is hardly ever heard, whereas when things are turning bad, as in recent times, there is a surge in AGMs attendance, media interest and coverage." 115 This activity, however, eventually dies out, notwithstanding the fact that "ironically, it is exactly when things are seemingly going peacefully when

\footnotetext{
${ }^{108}$ The former FRC Chairman honestly identified this when she stated that “...if the Commission concludes that stewardship has failed, that will push us inexorably down the road to more regulation and the further loss of rights which we - and you - rightly prize so highly.” Baroness Hogg, ICGN Conference, 20 March 2012. 
shareholders are needed the most to monitor directors." ${ }^{116}$ Not after things have turned out badly.

Similarly, does shareholder activism help companies thrive? Some argue that the evidence is simply not there, ${ }^{117}$ but, as Franks suggested "the Kay Review did not demonstrate that long-term shareholding versus activism was, of itself, better."118 Commentators have likewise identified dangers associated with excessive shareholder activism. In their view, investor activism may be dangerous if it 'gets out of control'. The risk, it is claimed, is that increasing shareholders' powers can lead to 'a 'deluge' of corporate governance votes that will have the undesired effect of "distracting managements and costing companies a small fortune." 119 This view has gained increasing support in the US seemingly based on the lack of evidence to back the claim that shareholder engagement is actually beneficial. There is scepticism about whether the "shifting balance of power between corporate boards and shareholders has been of benefit to the economy and the resulting rise in hedge funds' activist campaigns will be in the long-term interest of investors." ${ }^{120}$ However, detailed empirical research has shown that there is no evidence to suggest that hedge fund activism is detrimental to a company's long-term performance. ${ }^{121}$ Whichever is the case, part of the problems faced by the SC must stem from a lack of consensus regarding whether shareholder activism is, in fact, desirable.

\section{Facing the consequences}

Having established that the SC has not been a success and having reconsidered the reasons why, this article now seeks to establish that the SC is, ultimately, an ineffective corporate governance tool. Quite apart from the implementation and conceptual issues with the SC discussed in Section C above, the SC faces severe practical difficulties as well. These difficulties include: the SC's lack of enforceability, its triviality, lack of progressiveness and its unresponsiveness. Each of these issues will be dealt with in turn below.

\section{Enforceability}

\footnotetext{
${ }^{116}$ A Reisberg, supra $\mathrm{n} 114$.

${ }^{117}$ J Lorsch, a professor at Harvard Business School, and J Fox, the editorial director of the Harvard Business Review argue that "shareholders are not particularly well suited to be "corporate bosses"" as Nocera puts it bluntly. As Nocera explains, the thrust of their argument is that "[T]hey are too diffuse, and too short-term oriented, especially now that high frequency trading dominates the market. Indeed, despite the increased emphasis on shareholders in the past few decades, companies have not gotten noticeably better." J Nocera, 'Down With Shareholder Value' explained in The New York Times (10 August 2012) at: http://www.foreconomicjustice.org/4218/down-with-shareholder-value (accessed 2 December 2014). See, Harvard Business Review (July- August 2012): http://hbr.org/2012/07/what-good-are-shareholders/ (accessed 12 September 2013).

${ }^{118}$ Julian Franks speaking at an academic conference held on 23 January 2013 at the European Commission, Brussels to discuss the European Commission's Action Plan on Company Law and Corporate Governance which was published on 12 December 2012 and associated policy proposals. See, http://www.ecgi.org/conferences/eu_actionplan2013/report.php (accessed 12 January 2014).

J Fried calls this 'The Uneasy Case for Favoring Long-Term Shareholders' (18 March 2013). ECGI - Law Working Paper No. 200. Available at SSRN: http://ssrn.com/abstract=2227080 (accessed 12 January 2014). In relation to M\&A activity, the evidence seemed to suggest that where shareholder approval was required, the outcome was more profitable than those deals where no consent was required. Franks, ibid.

${ }^{119}$ In a recent paper published in the Columbia Law Review, Leo Strine, chief justice in Delaware, said that "it is counterproductive for investors to turn the corporate governance process into a constant Model U.N. where managers are repeatedly distracted by referenda on a variety of topics proposed by investors with trifling stakes." L E Strine Jr, 'Can We Do Better By Ordinary Investors? A Pragmatic Reaction to the Dueling Ideological Mythologists of Corporate Law' (2014) 114 Columbia Law Review 449, 475.

${ }^{120}$ Strine Jr, Ibid.

${ }^{121}$ L A Bebchuk, 'The Long-Term Effects of Hedge Fund Activism' (School of Business, Duke University 2013).
} 
The SC lacks an enforcement capability. As mentioned above, following the CGC's format, the SC adopted a 'comply or explain' approach. ${ }^{122}$ However, there are at least two problems with using this approach. Firstly, it is unlikely that institutions will "show immediate results in terms of compliance and a change in current practices". 123 In fact, studies into such comply-or-explain regimes have found that, in one out of five cases of non-compliance, companies do not bother providing any explanation. ${ }^{124}$ Even if companies did provide explanations, these explanations were not specific in identifying the exact circumstances that warranted deviations from the Code. ${ }^{125}$ Furthermore, with respect to the content of the compliance statements, there is disparity in terms of the information released by the institutional investors. ${ }^{126}$

Secondly, unlike the CGC, the effectiveness of the SC depends on an active role by secondary institutional investors (e.g. pension funds \& insurers) to assess fund managers' record of compliance (or in its case, the appropriateness of their explanations) with the SC's seven principles of stewardship in determining whether to allocate or renew a fund management mandate with them. ${ }^{127}$ In other words, the FRC has no active role in enforcing compliance with the SC. Furthermore, as Roach rightly pointed out, the SC does not have the backing of Listing Rules (that carry with them the threat of penalty upon non-compliance). ${ }^{128}$ In reality, not all investors see stewardship as a worthwhile concern - and even those who do, do not consider managers' non-compliance with the SC's principles to be a significant factor in evaluating their performance.

\section{Triviality}

A weak enforcement capability is exacerbated by the triviality of some of the SC's seven principles. The superficiality and lack of rigour that characterize some of its provisions have at best a neutral effect on eliciting meaningful institutional investor engagement - and at worst, a discouraging one.

Let us look, first, at Principle 3 of the SC to illustrate this. According to this principle, 'institutional investors should monitor their investee companies'. This provision is bland and inconsequential and does little to contribute towards actually achieving closer monitoring by shareholders. It is nothing but trivial. I seriously doubt anyone could think this 'biting' provision would contribute in any way towards reaching the SC's purported goals. The truth is that the SC principles do little - if not nothing - to

\footnotetext{
${ }^{122}$ According to the Financial Conduct Authority's Conduct of Business Sourcebook, Rule 2.2.3 “a firm, other than a venture capital firm, which is managing investments for a professional client that is not a natural person must disclose clearly on its website, or if it does not have a website in another accessible form: (1) the nature of its commitment to the Financial Reporting Council's Stewardship Code; or (2) where it does not commit to the Code, its alternative investment strategy." Financial Conduct Authority, Conduct of Business Sourcebook, COBS at: http://fshandbook.info/FS/html/FCA/COBS/2/2 (accessed 12 April 2014).

${ }^{123}$ K Sergakis, 'The Uk Stewardship Code: Bridging the Gap between Companies and Institutional Investors' 201347 RJT ns $109,135$.

${ }^{124}$ Ibid.

${ }^{125}$ Ibid.

${ }^{126}$ Ibid.

${ }^{127}$ As Glenister notes: "according to NAPF data, pension funds are increasingly taking note of investment manager behaviour in regard to stewardship of equity investments. Over $71 \%$ of funds now take the stewardship policies of their asset managers into account when looking at manager selection according to the trade group's 2012 Engagement Survey published in December of last year." And "Taken face value that seems significant. In truth, only handful of funds (7\%) actually exclude managers who cannot illustrate active stewardship. Almost a third (29\%) do not currently take stewardship into account and the remaining $64 \%$ only consider it to a limited degree. In short-term, stewardship is seen as a worthwhile concern but it certainly isn't a dealbreaker between clients and investment managers." See M Glenister, 'Will the Kay Review have a long-term impact on the investment chain?’ My Investor Circle, Peer Network Review, Corporate Governance, (5 April 2013).

${ }^{128}$ See Roach, supra n 4, 474.
} 
counteract the 'pervasiveness of the 'tick-the-box' compliance-monitoring strategies amongst investors in the UK' that - despite having practical benefits "in terms of reduced monitoring costs for investors -nevertheless completely undermine the value of the "comply or explain" principle by eliminating any scope for the transmission of firm-specific information conducive to the tailoring of governance arrangements to a company's unique features and circumstances." 129

\section{Non-progressive nature}

Another concerning issue involves the principle regarding management of conflicts of interest, namely Principle 2 of the SC. While generally the SC is very similar to the ISC Code, on this particular point, the SC seems to have taken a step backwards. Principle 2 of the ISC Statement of Principles (2002) called for "institutional investors to have a policy addressing how situations where institutional shareholders and/or agents have a conflict of interest will be minimised or dealt with." ${ }^{130}$ In contrast, the SC's Principle 2 requires only that "institutional investors should have a robust policy on managing conflicts of interests in relation to stewardship which should be publicly disclosed." This latter wording is ambiguous and loose. Unsurprisingly, it fails to make any real contribution towards enhancing the management of conflicts of interest between institutional shareholders and/or agents. In fact, the general view - as expressed even by the FRC - is that reporting under the $\mathrm{SC}$ of how "conflicts of interest are managed is frequently weak." ${ }^{131}$ For instance, the asset manager 2CG Limited issued a 'UK Stewardship Code Disclosure Statement' where it stated that it has a conflict of interest policy which manages and mitigates potential conflicts of interest. However, it fails to state the actual policy. ${ }^{132}$ Further, in response to the SC's Principle 4, which requires institutional investors to "establish clear guidelines on when and how they will escalate their activities as a method of protecting and enhancing shareholder value," the firm's response is extremely nondescript. It just states that they do not seek to take legal advice, but meet with management and make their views known.

\section{Unresponsiveness}

Finally, there are also practical concerns as to the unresponsiveness of the SC. Since the creation of the ISC in 1991, many investors, fund managers, investment consultants and service agencies have expressed varying levels of dissatisfaction. ${ }^{133}$ This means that on two different occasions - and disregarding the benefit of hindsight - the FRC has chosen not to take into consideration the suggestions expressed in consultations with those subject to the SC (or the ISC Code before 2010). ${ }^{134}$ For example, Principle 5 of the SC reads: "institutional investors should be willing to act collectively with other investors where appropriate." This principle rests on the

\footnotetext{
${ }^{129}$ Moore made this comment about the effects of the 'tick-the-box' approach with respect to the (then) Combined Code. See M Moore, 'Whispering Sweet Nothings: The Limitations of Informal Conformance in UK Corporate Governance' (2009) Journal of Corporate Law Studies 77, 120-121. However, the same dangers apply regarding its effects on the effectiveness of the 'comply or explain' approach under the SC.

${ }^{130}$ Institutional Shareholders' Committee, Code on the Responsibilities of Institutional Investors, 3.

${ }^{131}$ FRC, Developments in Corporate Governance (FRC, (December 2011),21 and again in FRC, Developments in Corporate Governance 2013 (December 2013), 26.

${ }_{132}$ Available at: http://www.2cg.com/docs/prospectus/stewardship.pdf (accessed 21 April 2014).

${ }^{133}$ See Roach, supra n 4, 476-477.

${ }^{134}$ On this issue, Manifest, one of Europe's largest proxy voting agencies, stated: “we do not welcome adoption of the [ISC] Code as it currently stands. The revised ISC Code presented to the FRC was not made the subject of market-wide, comprehensive stakeholder input." Manifest, "Stewardship Code" (Essex, Manifest, 2010), 3 as cited in Roach, supra n 4, 476.
} 
assumption that different asset managers can somehow come together through a forum to exercise collaborative stewardship. This collaboration is undoubtedly needed, particularly since fragmented shareholdings have brought new challenges to communication within companies. Different voices express diverging concerns and requests and there is a generalized lack of coherence in the messages that reach boards. Indeed, coordinating the multiplicity of shareholders is a major task that would require a supreme act of leadership by institutional investors - and Principle 5 is unlikely to motivate it.

However, there are recent glimmers of hope. In response to the Kay Review, the Collective Engagement Working Group was established in April 2013 and was supported by the ABI, IMA and NAPF. ${ }^{135}$ It looked at how institutional investors might be able to work together when engaging with listed companies in order to improve long-term company performance. ${ }^{136}$ This yielded the launch, in October 2014, of an 'Investor Forum'. ${ }^{137}$ The main objectives of the forum are twofold. The first is to encourage long-term investment and the second is to develop a model for effective engagement across the investment chain for UK companies. ${ }^{138}$ The forum will be made up of four separate forums, an innovation forum for cultivating research on leadership and development, an advisory forum which will provide confidential counsel to investors, a collective investment forum for facilitating collective engagement and an event driven forum aimed at protecting investor rights during material corporate change. ${ }^{139}$ However, there is still wide spread skepticism about whether the establishment of the Investors' Forum will be able to 'champion constructive engagement with companies. ${ }^{140}$

The preceding two sections leave us with two major lessons. First, the SC cannot be expected to solve the problem of institutional engagement in a vacuum, disregarding the problems that afflict "modern investment management practices and characteristics," ${ }^{141}$ exactly those "that make genuine stewardship so challenging for institutional investors." "142 Second, it is clear that the time has come for the FRC to step up its game and take a more comprehensive approach to monitoring companies, as outlined below.

\section{E. The Way Forward}

\footnotetext{
${ }^{135}$ See, http://www.investmentfunds.org.uk/current-topics-of-interest/investor-forum/ (accessed 6 May 2014). Note the recent merger between the Investment Affairs division of the ABI and IMA, which subsequently led to the Institutional Investor Committee being dissolved.

${ }^{136}$ Ibid.

${ }^{137}$ Ibid.

${ }^{138}$ The Investor Forum Discussion Paper (2014), 3.

139 Ibid, 12

${ }_{140}$ Ibid. As Lee (Director at Hermes Equity Ownership Services Ltd) explained: "We struggle to be convinced that the proposed investors' forum to coordinate and encourage more engagement will amount to much - it was last proposed only in 2009 in the Walker Report and the Institutional Investors Committee has not resurfaced substantially since - as it seems to place the bulk of the burden on the shoulders of investment managers, the intermediaries Kay rails against and yet he does not propose significantly to change their incentives. It is therefore hard to understand why more would actively seek to rise to the challenge he lays out." See, P Lee, 'Kay - repurposing the equities markets' (August 2012) 218 Governance, 7. Furthermore, as noted supra, any strategy requiring shareholder engagement requires the design of appropriate incentives to make foreign investor engagement involvement, including in this Investors' Forum, worthwhile and ensure they devote sufficient time to their investment affairs.

${ }^{141}$ Reisberg, supra n 4, 140

${ }^{142}$ Ibid.
} 
A simplistic approach to the problem of stewardship is insufficient. A piecemeal approach would not work either. The best way to ensure enhanced monitoring of companies is to adopt a comprehensive approach that joins efforts across the board: from investment intermediaries to clients; from corporate governance mechanisms to the reform of the investment management industry. ${ }^{143} \mathrm{~A}$ multi-layered approach that is sensitive to the roles and needs of all players should enable a comprehensive review to pin down the issues that make stewardship challenging for shareholders nowadays and address the SC's weaknesses accordingly. ${ }^{144}$ This could well become an overwhelming task, so it is essential to prioritise. In this respect, it would also be helpful to set clear, achievable targets amongst the various players, namely, (1) regulators, chiefly, the FRC; (2) the investment industry; and finally (3) the role of the clients. For descriptive reasons, the discussion below follows this division, although, there are, naturally, overlapping issues that involve or require collaboration of some or all of the players.

\section{What should the FRC do next?}

The FRC have stated that their current priority is the encouragement of greater commitment to the SC by its signatories. ${ }^{145}$ It is suggested that there are at least three improvements that need to be made in order to do this.

First of all, the concept of stewardship needs, finally, to be clarified in the SC and the role of each one of the players along the investor chain and their respective stewardship responsibilities distinctly identified and delineated. As part of this, it is also essential to ensure key players are accountable for their stewardship responsibilities, thus the FRC needs to work to establish clear criteria and metrics by which engagement can judged. ${ }^{146}$ It is equally essential to clarify the meaning of fiduciary duties as applied to investment fiduciaries. The SC should emphasise that this fiduciary duty requires them to act as guardians of companies' long-term, sustainable growth, and their performance should be measured accordingly. The UK Government has already set out important strategies to this aim. ${ }^{147}$ The recommendations issued in response to the Kay Review include setting "common minimum standards of behaviour required of all investment intermediaries" to ensure they act "in the best long-term interests of their clients or beneficiaries." 148 To that effect, the Law Commission "has been asked to review the legal obligations on intermediaries, to take appropriate long-term factors into account recently. “" ${ }^{149}$ In

\footnotetext{
${ }^{143}$ This move towards reforming the industry (discussed below) is certainly to be welcomed. Whether it would go far enough or make any impact remains to be seen.

${ }^{144}$ This notion seems now to have finally registered with the FRC: "The objectives of the Stewardship Code... are not ones that can be achieved through the Code alone, and the FRC will continue to work closely with the market and other regulators to deliver them." See, FRC, Developments in Corporate Governance 2013 (December 2013), 23.

${ }^{145}$ FRC, ibid, 4

${ }^{146}$ As mentioned above, the FRC identified this need when in a 2011 report it stated that "(The) FRC also hopes to stimulate discussion around performance metrics that can help all parties know what the Stewardship Code is achieving. This will hopefully provide visible confirmation that the market is building on the year's good start and delivering meaningful change." See FRC, Developments in Corporate Governance (December 2011), 31. However, four years later nothing seems to be happening in this regard.

${ }^{147}$ DBIS, The Government Response to the Kay Review (November 2012):

http://www.bis.gov.uk/assets/biscore/business-law/docs/e/12-1188-equity-markets-support-growth-response-to-kay-review (accessed 16 January 2014). And see further DBIS n 30.

${ }^{148} \mathrm{Ibid}$, para 3.34 .

149 See, DBIS 'Government sets out steps to change culture in UK equity markets' (22 November 2012) at:

http://news.bis.gov.uk/Press-Releases/Government-sets-out-steps-to-change-culture-in-UK-equity-markets-683c1.aspx (visited 16 January 2014). As part of the responses to the Kay Review, On 22 October 2013 the Law Commission published a
} 
addition, "[T]he FSA [now FCA] has also been asked to ensure that the regulatory framework promotes high standards of behaviour throughout the investment chain." 150

These clarificatory tasks go hand in hand with what should be the FRC's second priority: to analyse who can realistically be expected to be engaged and to what extent. The SC should not focus on all institutional shareholders by default. Rather, it should adopt a more progressive approach and allocate responsibilities depending on the varying incentives players may have to monitor companies and the potential they have to do so in an efficient way. The nature and extent of stewardship responsibilities may vary from one type of investor to the other. The SC must be sensible to the fact that investors who choose different investment models are likely to have dissimilar interests and be driven by diverse incentives. Investors who choose a short-term-oriented investment model may have to be treated differently from those who choose a long-term one. Identifying this and tailoring responsibilities accordingly may facilitate collaboration between investors of the same type and reduce engagement costs. For example, long-term investors seem to have similar interests regardless of whether they are domestic or foreign, and, accordingly, it is more likely that long term strategies will be implemented by them. ${ }^{151}$ Indeed, Edmans explains that "the main distinction is not between short-term and long-term shareholders but rather between large and small shareholders." 152 As Edmans suggests, this means that "shareholders, who are short-term and uninformed, would trade on short-term earnings, ${ }^{153}$ whereas only long-term shareholders would implement long-term policies." 154 A second, and equally important way forward, would be "to demand long-term metrics from companies to inform investment decisions." 155 The idea being that it is difficult to reach long term investment decisions "without metrics that calibrate, even in a rough way, the long-term performance and health of companies." 156

consultation paper reviewing how fiduciary duties apply to investment intermediaries. See, Fiduciary Duties of Investment Intermediaries at: http://lawcommission.justice.gov.uk/news/2565.htm (visited 18 January 2014). David Hertzell, the Law Commissioner leading the project, said: "Judge-made laws, such as fiduciary duties, cannot make up for gaps in regulation. We think that there may be gaps in the way that investment consultants and custodians are regulated, and ask whether there is a need to review these areas." Ibid. In its July 2014 Report it concluded, amongst other things that "pension fund trustees do not have to "maximise returns" in the short-term at the expense of risks over the longer term." And that "whilst the pursuit of a financial return should be the predominant concern of pension trustees, the law is sufficiently flexible to allow other, subordinate, concerns to be taken into account. The law permits trustees to make investment decisions that are based on non-financial factors..." Statement at: http://lawcommission.justice.gov.uk/publications/fiduciary duties.htm (accessed 3 December 2014). ${ }^{150}$ DBIS, ibid.

${ }^{151}$ A Edmans, 'Corporate Governance and Short-Termism: Challenges and Solutions' a presentation at the European Corporate Governance \& Company Law Conference in the Convention Centre, Dublin (16 May 2013) at: http://www.corpgov2013.com/delegate-info.php\#PRESENTATIONS (accessed 15 January 2014). 152 Edmans, ibid, in A Reisberg, 'The Role of Institutional Shareholders: Stewardship and the Long-/Short-term Debate' in The Law on Corporate Governance in Banks (Elgar Financial Law Series) (Forthcoming, 2015).

${ }^{153} \mathrm{Ibid}$. If they are small and short, looking at earnings would give incentives to management to boost earnings.

${ }^{154} \mathrm{Ibid}$. As Edmans explains "larger shareholders have greater incentives to gather information (or 'sufficient skin in the game' as he calls this). Instead of having a portfolio in 200 companies they own portfolios with larger stakes in a few companies. And, if, for example, there is cut in dividends, they will try to understand what's behind it. If it is to finance investment in the long run they may hold the shares, but if it is due to management mismanagement they are more likely to sell their shares. Exit, in many cases can be an act of governance of disciplinary the management, contrary to what people think. So selling the shares would be a vote of no confidence in the current board." Ibid.

The recent Royal Mail controversial £3.3bn privatisation may, nonetheless, cast a shadow on this view. It was reported by Sky News that a group of 16 large investors (including two large sovereign wealth funds, namely, "the Kuwait Investment Office and the Government Investment Corporation of Singapore (GIC)) were chosen by the Government's advisers as part of an attempt to establish a long-term investor base for Royal Mail when it sold shares in the company last autumn. That said, the National Audit Office (NAO) reported that $75 \%$ of those funds had subsequently sold part or all of their holdings in order to cash in on the instant surge in Royal Mail's share price.” See, Sky News, 'Singapore Fund Was 'Core' Royal Mail Investor '(29 April 2014) at: http://news.sky.com/story/1251452/singapore-fund-was-core-royal-mail-investor (accessed 30 April 2014).

${ }^{155}$ D Barton and M Wiseman, 'Focusing Capital on the Long Term' Harvard Business Review (January-February 2014$) 44,47$.

${ }^{156} \mathrm{Ibid}, 50$. Barton and Wiseman explain further that "focusing on metrics like 10-year economic value added, R\&D efficiency, patent pipelines, multiyear return on capital investments, and energy intensity of production is likely to give investors more 
Thirdly, it is clear that FRC must now adopt a more active and visible approach to monitoring companies (beyond the annual reports which highlight gaps and areas for improvements) if it wants to tackle what it now calls an 'engagement deficit' ${ }^{157}$ This should take the form of randomised or enhanced inspections of compliance to the SC coupled with 'naming and shaming' and possibly sanctions for unhelpful or below the par statements. ${ }^{158}$ Hand in hand with this, the FRC should not be shy of sharing 'best practice' statements that could set the standard for the rest of the industry, in particular if, indeed, "[T]here are some very good examples of clear and specific reporting by Stewardship Code signatories." 159 This will help drive a gradual change over time.

Incorporating the last three suggestions would contribute significantly to the working of the SC. At the moment, however, the SC falls short on every side: stewardship is incompatible with the incentives of investors holding short positions. At the same time, it fails to provide incentives for long term, value-oriented investors which may be discouraged from engaging with their companies because of the well-known 'freerider' issue. Finally, as already mentioned, it fails to engage foreign investors sufficiently.

\section{What should the investment industry do next?}

First, a way needs to be found to tackle the problem of fragmented shareholdings that reduces the incentives for stewardship. ${ }^{160}$ This is a monumental barrier which cannot be solved over night or easily. Yet, one option to mitigate this problem is to work towards the design of "a formalised process for a chain of engagement" ${ }^{161}$ that provides the proper incentives for each one. Likewise, "fund managers should incorporate corporate governance opinions into their buy/sell decisions." 162 This would encourage discussions "on a broader range of issued in a more informed way" and create incentives to require boards to provide detailed information about the companies' strategy and risk ("and not just small print details of the financial and the box-ticking aspects of governance"). ${ }^{163}$ The issue of foreign investors is present here

useful information than basic GAAP accounting in assessing a company's performance over the long haul. The specific measures will vary by industry sector, but they exist for every company." Ibid. Another possible way of "judging the quality of the stewardship activities offered by individual asset managers" (FRC, Developments in Corporate Governance 2013 (December 2013), 24) would be to use NAPF's Stewardship Disclosure Framework, published in October 2013, which calls for managers to self-certify against categories based around the principles of the SC. NAPF, Stewardship Disclosure Framework for Asset Managers; (October 2013)

${ }^{157}$ FRC, Developments in Corporate Governance 2013 (December 2013), 21. Unsurprisingly, to date, engagement under the SC has been very focused on remuneration (ibid, 22), but engagement needs to broaden if the SC is to make any progress.

${ }^{158}$ Magnier, in the context of corporate governance codes in the EU, similarly calls for randomised inspections on Code compliance conducted by market authorities with the results published and sanctions imposed for dishonesty. See, V Magnier, 'Harmonization Process for Effective Corporate Governance in the European Union: From a Historical Perspective to Future Prospects' (2014) 41 Journal of Law and Society 95, 117. Indeed, this is something the FRC appears now ready to take on: “The FRC is considering mechanisms for ensuring that statements are complete and up to date, and possible sanctions where they are not." FRC, supra n 157, 29.

${ }^{159}$ FRC, supra n 157, 26

${ }^{160}$ As Kay explained: "institutional investors who own less than one per cent of a company do not have sufficient incentive to become good stewards." See, Kay Review, supra, n 49, 13.

${ }^{161}$ That is from clients, to investment intermediaries and then investee firms. Ibid. M Glenister, 'Will the Kay Review have a long-term impact on the investment chain?' My Investor Circle, Peer Network Review, Corporate Governance, (5 April 2013). Available at:

http://www.myinvestorcircle.com/feature/will-kay-review-have-long-term-impact-investment-chain (accessed 17 March 2014).

${ }^{162}$ Former FRC Chairman Baroness Hogg, ICGN Conference, (20 March 2012), 5, available online at:

https://frc.org.uk/FRC/media/Documents/ICGN-conference_20-March-2012.pdf (accessed 12 November 2014).

${ }^{163}$ Ibid. 
too. While engaging them may prove to be harder, they should, at least, be offered better incentives (as explained next). A more progressive option, advocated by Gilson and Gordon, is to delineate and further specialise the roles of different investors. ${ }^{164}$ This would mean hedge funds and the like would be classified as activist investors and tasked with the identification of corporate governance issues, whereas institutional investors would review their proposals and decide on which ones to pursue whilst retaining their specialisation in portfolio management. ${ }^{165}$

Along similar lines to Gilson and Gordon, this writer argues that one needs to identify which institutions can ideally act as stewards while at the same time discount those institutions or investors who are less active or who are less capable in investing time and efforts looking into a company's governance and results. ${ }^{166}$ In other words, specialisation is necessary, however, instead of drawing distinct lines of responsibility between hedge funds and other institutional investors, it is suggested that policymakers should distinguish between short-term investors versus potential stewardship investors, and regulatory steps pursued accordingly to facilitate stewardship amongst the latter. How would one go about this task? Following Belinfanti, one helpful line can be drawn between different type of industries, namely, "slow-growth industries like utilities and manufacturing are generally thought to attract so-called "income" investors who focus primarily on the stream of dividends a given stock is likely to generate", ${ }^{167}$ whereas "high-growth industries, such as emerging technologies or green-building construction, tend to attract "growth" investors, who focus primarily on the underlying quality of the business and the rate of expected growth, as opposed to immediate value and so-called "GARP" ("growth at a reasonable price") investors." 168 A second dimension Belinfanti highlights, which can help identify which investors can potentially act as stewards, relates to the type of fund in question, for example, index funds, i.e. funds whose share "portfolio is constructed to match or track a market index." ${ }^{, 169}$ It is suggested these investors "do hold for relatively longer periods of time and continue to invest in the stock so long as the stock remains in the relevant index." ${ }^{170}$ Necessarily all of the above require that institutional investors allocate greater resources to stewardship activities. On this point, Barton and Wiseman pointedly remind us that "[A]ction must start with large asset owners such as pension funds, mutual funds, insurance firms, and sovereign wealth funds. If they adopt investment strategies aimed at maximizing long-term results, then other key players - asset managers, corporate boards, and company executives-will likely follow suit."171

It is likewise clear that governance budgets cannot remain stagnant if investors are to be able to engage effectively. Better-prepared and more senior staff would be needed to assume leading roles in the corporate governance dialogue. This issue requires a lot of thought because if costs remain too high, this discourages engagement. The FRC

\footnotetext{
${ }^{164}$ Gilson and Gordon, supra n 69.

${ }^{165}$ Gilson and Gordon, supra n 69, 897.

${ }^{166}$ D Arsalidou, 'Shareholders and Corporate Scrutiny: The Role of the UK Stewardship Code' (2012) 9 ECFR $342,375$.

${ }^{167}$ T Belinfanti, 'Shareholder Cultivation and New Governance'(2014) 38 Del J Corp L 789, 818 relying on A Damodaran, Investing Basics Analyzing Stocks, NY University Stern School of

Business ,http://pages.stern.nyu.edu/ adamodar/New Home Page/articles/valbasics.htm ("categorizing investors as either

"value," "growth," "income," "GARP," ("growth at a reasonable price") or "quality," and discussing the kind of company

qualities each type of investor will seek)." Ibid.

168 Ibid, 819 .

${ }^{169}$ Ibid, 871

${ }^{170}$ Ibid.

${ }^{171}$ D Barton and M Wiseman, supra n 155, 51.
} 
have a role to play here too in working together with institutional investors and the government to find cost-effective engagement strategies that make it "easier and more profitable for investors to incorporate quality engagement into their investment strategies." 172 Here, again it is time for the FRC to consider more practical solutions. These could include rewarding worthy or meaningful stewardship by means of financial incentives, such as "weighted dividends whose dividend stream is dependent on a shareholder's length of ownership" 173 or the more nuanced option of "missionweighted dividends whose dividend stream depends on the quality of share ownership." 174 Another option, which has surfaced numerous time before, would centre on so-called "long-term tax benefits for good stewards". ${ }^{175}$ Finally, some authors have pointed out to solutions endorsed in France, for example, which provide long-term shareholders with enhanced voting rights. ${ }^{176}$ The thrust of the argument is that a two-tier system would solve the problem of overseas investors discussed above, as if these investors will be "convinced they will stand to benefit from constructive engagement with boards", this would "bind them more closely into long-term active ownership of the company". ${ }^{177}$ But it is hard to believe that a two tier system would be welcomed in the UK. Instead, for practical reasons, it is submitted that mechanisms that foster collaboration should be encouraged. This will keep down engagement costs, not only for shareholders but also for companies. Strategies to achieve concert are paramount. One way to do this and bring uniformity may be assumed by the investors' forum discussed above. ${ }^{178}$

A final issue that has been identified as hampering engagement is the increasing use of proxy voting agencies. Therefore, the SC should require disclosure of proxy voting guidelines detailed statements on agencies' views on good corporate governance practices and cover "issues such as board structure, remuneration policy and management of social and environmental issues." 179 They should also promote meaningful commitment to the implementation of policies throughout companies directed towards achieving shareholders' long-term benefit. Further, the SC should make use of technology available nowadays that would facilitate shareholder involvement. ${ }^{180}$

\footnotetext{
${ }^{172}$ Glenister, supra $\mathrm{n} 161$.

${ }^{173}$ Belinfanti, supra $\mathrm{n} 167,845$

${ }^{174}$ Belinfanti, ibid. See also, Reisberg, supra n 4, 141. Under a 'mission-weighted dividends': "Shareholders who exhibit some amount of stewardship characteristics would receive superior dividend rewards as compared to a non-co-venturer shareholder." Belinfanti, ibid, p. 853. As Belinfanti explains 'the stewardship characteristics' will clearly be defined by each company and could, for instance, follow the SC principles. Belinfanti, $i b i d$.

${ }^{175}$ See Reisberg, supra n 4, 132. For a detailed discussion of the various proposals utilising the tax system to make long-term ownership more attractive see, A Reisberg, supra n 152, para 4.41. For example, Stiglitz and Larry Summers in 1989 (drawing on Keynes's suggestion from 1936) called for a tax on transactions in the stock market arguing this "could lead to an increase in the relative number of long-term investors, causing managers to shift their focus to the long run." J Fried, 'The uneasy case for favoring long-term shareholders' Harvard Law School; European Corporate Governance Institute (ECGI) Working Paper No 200 (18 March 2013), 22, citing J Stiglitz, 'Using tax policy to curb speculative short-term trading' (1989) 3 J Fin Serv Res 101, 109. It may also be a good idea to start calling those who choose engagement 'assets stewards' instead of 'assets mangers' to reflect their commitment to the process.

${ }^{176}$ D Arsalidou, 'Shareholders and Corporate Scrutiny: The Role of the UK Stewardship Code' (2012) 9 ECFR 342, $376-377$.

${ }^{177}$ Ibid, 378 and Belinfanti, supra, n 167, 847.

${ }^{178}$ As suggested in the Kay Review. See, M Glenister, 'Will the Kay Review have a long-term impact on the investment chain?' My Investor Circle, Peer Network Review, Corporate Governance, (5 April 2013).

${ }^{179}$ PIRC, UK Shareowner Voting Guidelines 2014 at: http://pirc.co.uk/news-and-resources2/guidelines (accessed 2 December 2014).

${ }^{180}$ For example, the Kay Review recommended that "government should explore the most cost effective means for individual investors to hold shares directly on an electronic register." Kay Review, supra n 49, 13. The EU Green Paper also recommended the development of an "EU proxy solicitation system where listed companies would be required to set up a specific function on their website enabling shareholders to post information on particular agenda items and seek proxies from other shareholders." European Commission Green Paper, The EU Corporate Governance Framework 2011, European Commission, COM, (April 2011). Available at:

http://ec.europa.eu/internal_market/company/modern/corporate-governance-framework_en.htm (accessed 12 April 2014).
} 
In short, there are a number of options available to the FRC to tackle the engagement deficit. At the very least the FRC should collaborate with regulators, the industry and clients to reform the industry itself to (i) eliminate unnecessary intermediation and strengthen internal capabilities; (ii) revamp performance metrics and other arrangements; ${ }^{181}$ (iii) rationalise portfolio holdings; (iv) re-orient the passive investing model; and (v) clarify fiduciary duties.

\section{And finally: let's talk about the clients}

Finally, we should be clear that no single actor is able to achieve positive results acting alone. Adopting new principles, rules and standards will be useless unless they are met with a receptive attitude and willingness to comply. Historically this attitude has not been forthcoming. For example, in a 2012 statement, Amanda McCluskey, head of responsible investment at First State Investments in Sydney, said that the company has not signed up to the SC because "we do not think it will change the industry. We want harder questions, we need to be challenged, and we have to do something more than simply signing up to the code." "182 All parties need to understand that these changes need to happen for the benefit of all. It is essential, therefore, that clients have a more active role in this process. In fact, their involvement has been described as key to revolutionizing the engagement between investors and companies, ${ }^{183}$ as well as critical for the elimination of the structural deficiencies that hinder stewardship today. This view relies on client pressure as the best driver of behavioural change, because ultimately, members are responsible to their clients. ${ }^{184}$ According to this view, if clients wish to see investment managers change or develop new approaches they should push for that. ${ }^{185}$

\section{F. Conclusion}

This writer would have wished to end this article on a more optimistic note. Indeed, both Sir David Walker ${ }^{186}$ and John Kay now concede "that the investment environment that they ultimately sought, in which the 'anonymous trader' was

\footnotetext{
${ }^{181}$ According to Wong "if investment managers are relieved of the strain to "outperform" each quarter, they may in turn focus less on short-term performance at investee companies." See Wong, supra n 47. On 17 October 2013, the Council of the EU adopted the proposal for a directive to amend the Transparency Directive (2004/109/EC) (the "Amended Transparency Directive"). Member States will then be required to transpose the amendments into national law within two years and, as such, the long-stop date for implementation of the Amended Transparency Directive will likely be around the end of 2015. Among other things, the Amended Transparency Directive abolished the obligation for certain issuers to publish interim management statements (IMS - quarterly reporting). However, this does not prevent some issuers that may take the view that to meet investors' expectations they should continue to publish such statements or quarterly financial reports, from doing so. See Directive 2013/50/EU of the European Parliament and of the Council of 22 October 2013 amending Directive 2004/109/EC at: http://eurlex.europa.eu/legalcontent/EN/ALL/;jsessionid=myQgT2XFycXpJ2zpML8kj6sPnHyQw4yjkFs2M12MPJWcfR81dbR 3!-1709783680?uri=CELEX:32013L0050 (accessed 12 April 2014).

182 N Rohrbein, 'UK Stewardship Code 'will not change investment industry' First State, Investment \& Pensions Europe (March 2012). Available at:

http://www.ipe.com/uk-stewardship-code-will-not-change-investment-industry-first-state/44498.fullarticle (accessed 21 April 2014).

${ }^{183}$ See, P Lee, 'Kay - Repurposing The Equities Markets' (August 2012) 218 Governance, 6-7.

${ }^{184}$ Ibid.

${ }^{185}$ Ibid. The FRC now recognises this too: "Ultimately, greater client demand will be the key to increased monitoring and engagement by asset managers. There are some signs this is beginning to happen, and many owners have told the FRC that the biggest merit of the Stewardship Code was that it had normalised their right to ask for stewardship as a routine matter for consideration.” FRC, Developments in Corporate Governance 2013 (December 2013), 23.

${ }^{186}$ The person who first suggested in 2009 that the FRC takes responsibility for the SC.
} 
replaced by the "concerned investor' remained a long way off." "187 Although "there was a widespread desire for shareholders to take more long term views [...] in line with the [...] the stewardship code", Sir David Walker believes this "will not happen overnight, and it may never happen." 188 As we saw, even the FRC now admits the presence "of an emerging "engagement deficit" affecting mid-market companies,"189 recognising that "there are some real impediments to effective engagement.",190

This is hardly surprising. As was seen above, the SC is a weak code, one which at its heart lays an amorphous concept - that of stewardship- which has no definite form and which means different things to different players. Its boundaries are rather weak and, accordingly, it can be stretched and applied in variable ways. Ironically, but not unexpectedly, there are now, reportedly, teams of people (as with CSR and compliance), whose entire role is to deal with SC and its application. ${ }^{191}$

It appears we are now at a crucial crossroad. As it stands, the SC's 'future is not certain, ${ }^{192}$ and it is now time 'to work it out', ${ }^{193}$ not let the future work it out by itself. The way forward, as articulated above, is to get involved in the debate and make sure that the real issues are being debated properly, prioritised and then, ultimately, implemented. The UK, with its rich experience with codes, should draw from that experience as well as that of other jurisdictions and working groups that have seen some progress in eliciting shareholder engagement. ${ }^{194}$ As for the rest of us, a prudent advice would be not to 'jump on the bandwagon' unless we know in which direction we are heading, lest we may end up on 'the road to nowhere'. ${ }^{195}$

\footnotetext{
${ }^{187}$ House of Lords House of Commons 'Changing banking for good' Report of the Parliamentary Commission on Banking Standards, para 663 of volume II .HL Paper 27-II (June 2013).

${ }^{188}$ As cited in ibid.

${ }^{189}$ With respect to engagement on a wider range of issues, not just on remuneration. FRC, Developments in Corporate Governance 2013 (December 2013), 4. The disappointing focus on remuneration and the need to broader engagement was also echoed in a speech given by Stephen Haddrill, CEO, FRC at a seminar 'Boards and Shareholders in UK, Italian and European Listed Companies', London Stock Exchange on 8 May 2014.

${ }^{190}$ FRC, Ibid, 21

${ }^{191}$ The FRC has called for each supporting institution to name an individual who is the main contact in relation to stewardship matters. For a couple of recent examples of these teams from industry see: (1) Fidelity's statement on compliance with the SC from December 2013: “ The corporate finance group has a specific responsibility to support FIL's stewardship and engagement activities...FIL also maintains an in-house team of governance specialists who are responsible for conducting our voting activities." https://www.fidelity.co.uk/investor/about/uk-stewardship-code/uk-stewardship-code.page (accessed 30April 2014); (2) Hermes: http://www.hermes.co.uk/Portals/0/documents/HFML\%20Stewardship\%20Code.pdf (accessed 30 April 2014).

${ }^{192}$ Road To Nowhere, supra $\mathrm{n} 1$. The word 'not' is my addition.

193 Ibid.

${ }^{194}$ Such as the Dutch Corporate Governance Code or the Singapore Code of Corporate Governance. See also the Australian Responsible Investment Australasia (RIAA) which in August 2013 launched a working group to "test models of better collaboration and information sharing on engagements amongst RIAA's membership." See, RIAA, 2013 Progress Report, 8 http://www.responsibleinvestment.org/wp-content/uploads/2014/01/Progress-Report.pdf (accessed 6 May 2014).

${ }^{195}$ Road To Nowhere, supra $\mathrm{n} 1$.
} 